FEDERAL RESERVE BANK OF SAN FRANCISCO

WORKING PAPER SERIES

\title{
Bank Linkages and International Trade
}

\author{
Julian Caballero \\ IADB \\ Christopher Candelaria \\ Stanford University \\ Galina Hale \\ Federal Reserve Bank of San Francisco
}

February 2016

Working Paper 2013-14

http://www.frbsf.org/publications/economics/papers/2013/wp2013-14.pdf

The views in this paper are solely the responsibility of the authors and should not be interpreted as reflecting the views of the Federal Reserve Bank of San Francisco or the Board of Governors of the Federal Reserve System. 


\title{
Bank Linkages and International Trade
}

\author{
Julian Caballero \\ IADB \\ Christopher Candelaria \\ Stanford University \\ Galina Hale* \\ Federal Reserve Bank of San Francisco
}

FEBRUARY 11, 2016

\begin{abstract}
We uncover a new channel through which international finance is related to international trade: formation of international bank linkages increases exports. Bank linkages are measured for each pair of countries in each year as a number of bank pairs in these two countries that are connected through cross-border syndicated lending. Using a gravity approach to model trade with a full set of fixed effects (source-year, target-year, source-target), we find that new connections between banks in a given country-pair lead to an increase in trade flows between these countries in the following year. We conjecture that the mechanism for this effect is the role bank linkages play in reducing export risk and present six sets of results supporting this conjecture. In particular, using industry-level trade data and controlling for country-pair-year and industry fixed effects, we find that new bank linkages have larger impacts on trade in industries with more differentiated goods, i.e. industries which tend to be subject to more export risk. Moreover, for U.S. banks, we can show that bank linkages are positively associated with foreign letter of credit exposures. Finally, we find that the formation of new bank linkages creates trade diversions from countries competing for similar imports.
\end{abstract}

JEL classification: F14, F15, F34, F36, G21

Keywords: International Trade, Financial Networks, International Banking, Gravity, Export risk

\footnotetext{
*galina.b.hale@sf.frb.org, corresponding author. We benefitted tremendously from comments by Joshua Aizenman, George Akerlof, Matthieu Bussiere, Yiwei Fang, Reuven Glick, Kathleen Hanley, Oscar Jordá, Sebnem KalemliOzcan, Sylvain Leduc, Gian-Maria Milesi-Feretti, Fernanda Nechio, Maury Obstfeld, Jennifer Poole, Matt Pritzker, Guillermo Vuletin, Shang-Jin Wei, Thomas Wu, seminar participants at the Banque de France, the International Monetary Fund, the Board of Governors of the Federal Reserve, UC Santa Cruz, USC Marshall School of Business, IDB, and the Federal Reserve Bank of San Francisco, as well as conference participants at the CEPR-BOF meeting in Helsinki, the Santa Cruz Institute for International Economics, and the NBER. We are grateful to Akshay Rao, Paula Cifuentes, and Mauricio Pinzón for excellent research assistance. We are also in debt to the U.S. EXIM bank and Cynthia Holbrook for help in obtaining the data. All errors are ours. The findings, interpretations, and conclusions expressed in this article are entirely those of the authors. They do not necessarily represent the views of the Federal Reserve System, or the Inter-American Development Bank, its Executive Directors, or the countries it represents.
} 


\section{Introduction}

The Global Financial Crisis, which erupted as a result of the U.S. subprime mortgage crisis, brought international financial markets to a standstill and severely disrupted international trade (Alessandria et al., 2011; Bems et al., 2013; Chor and Manova, 2012). Since then, researchers have highlighted the importance of the relationship between finance and international trade (see surveys by Manova and Foley, 2015 and Contessi and de Nicola, 2012). We contribute to this growing literature by testing whether bank linkages facilitate international trade. We assert that linkages between banks have a positive effect on international trade by alleviating risks associated with international trade transactions. Although only a small fraction of trade transaction payments are intermediated by banks, we empirically demonstrate that there is a positive effect of bank linkages formed through long-term interbank lending on export flows. ${ }^{1}$ We conjecture that bank linkages help reduce the risk that exporters face and provide evidence supporting this conjecture.

Our analysis is based on the standard gravity model framework outlined in Feenstra (2004). We augment the model by adding an export risk factor, which we interact with our measure of bank linkages. This simple framework predicts that bank linkages are positively associated with trade; however, this relationship becomes stronger when the export risk factor is larger. We test the model predictions using bilateral trade data from COMTRADE and employing both aggregateand industry-level regressions using data for 66 countries for the period 1990-2013.

We proxy for the tightness of bank linkages for each country pair using individual loan-level data on syndicated loans extended to banks from the Dealogic's Loan Analytics database. ${ }^{2}$ There are three reasons why syndicated loans are a suitable proxy for bank linkages: first, they tend to be large and are extended for a medium term (median is 3 years), which likely leads to substantial information acquisition by lenders; second, data are available on borrowers as well as lenders, which allows us to construct bilateral linkages; third, international syndicated loan markets are large and active. We construct a global network of banks in which relationships are formed when banks extend syndicated loans to each other. ${ }^{3}$ In constructing the network, we take into account the direction of the lending, but we ignore the amounts lent. We aggregate individual bank linkages by computing the sum of linkages formed by all bank loans extended by banks in country $i$ to banks

\footnotetext{
${ }^{1}$ Antràs and Foley (2015) estimate this share to be about 17 percent, while Niepmann and Schmidt-Eisenlohr (2013) measure it to be 10 percent of U.S. goods exports.

${ }^{2}$ For a detailed description of international syndicated loan market, see Cerutti et al. (2015).

${ }^{3}$ In this paper, we differ from Garratt et al. (2011); Kubelec and Sá (2010); Minoiu and Reyes (2013); von Peter (2007), who construct banking networks at the aggregate level, using BIS data. See Hale (2012) for the discussion of advantages of the bank-level approach and Cerutti et al. (2015) for the comparison of the coverage of syndicated loan and aggregate data sets.
} 
in country $j$. It is important to note that most linkages in our data do not have any direct or even indirect connections to trade activity. ${ }^{4}$

We begin our empirical analysis by testing whether bank linkages formed between two countries in a given year affect trade between these two countries in the following year. Since bank linkages vary by country pairs and over time, we are able to control for a full set of fixed effects: country-pair, exporter-year, and importer-year in our preferred specifications. We find that new bank linkages formed through bank lending in country $i$ to country $j$ in year $t-1$ are positively associated with exports from $i$ to $j$ in year $t .^{5}$ Increasing the change in the intensity of bank linkages due to new banking connections by 50 percent (about a 1 standard deviation change) is associated with an increase in trade in the subsequent year of about 10 percent. This large effect, however, is partly due to common factors affecting both trade and bank linkages across country pairs and over time. Once we control for the full set of fixed effects, we find the effect of the same change in bank linkages is associated with a 1 percent increase in international trade.

We also find that the effect of bank linkages on exports from country $i$ to country $j$ is larger for exports to countries with weaker contract enforcement, where lower levels of contract enforcement result in higher export risk (Anderson and Marcouiller, 2002). Following Berkowitz et al. (2006) and Antràs and Foley (2015), we proxy for contract enforcement using the International Country Risk Guide (ICRG) index and find that the effect of bank linkages is twice as large for exports to countries with weak legal and political institutions. We confirm this finding using three additional proxies for contract enforcement and export risk: credit rating from $\mathrm{S} \& \mathrm{P}$, insurance premium on exports to each country provided by the U.S. Exports-Imports bank, and OECD membership. We find that for exports to countries with credit rating of $\mathrm{A}+$ or higher, bank linkages do not matter, while for countries with credit rating of BBB- or lower, they are twice as important relative to the average estimate for the sample. Bank linkages are only important for exports to countries for which export insurance premium exceeds the average by about 0.8 of a standard deviation. Similarly, using OECD membership as a crude proxy of contract enforcement, we find that for exports from any country to an OECD country, bank linkages have no effect; however, for exports from an OECD country to a non-OECD country bank linkages have a positive effect.

Having established that there is a positive effect of bank linkages on export flows, where the estimated effect is larger in countries with weaker contract enforcement, we then test whether the effect is larger for differentiated goods than for either homogeneous goods or goods traded based on

\footnotetext{
${ }^{4} \mathrm{~A}$ negligible subset of loans in our data, 0.1 percent in terms of the number of loan tranches, is extended as back-up credit lines for trade credit, but most trade financing does not take form of inter-bank syndicated loans.

${ }^{5}$ We tested to see whether bank linkages formed by bank lending in country $j$ to banks in country $i$ affect exports from $i$ to $j$, but we found no empirical evidence supporting this.
} 
reference prices. Our product classifications come from Rauch (1999). ${ }^{6}$ By performing these tests, we contribute to the the extant literature suggesting that trade involving more differentiated goods is subject to heightened export risk because the enforcement of trade contracts is more difficult with respect to differentiated goods. There are several reasons why this may be the case. More differentiated products possess more complex characteristics, making it difficult to fully stipulate all relevant characteristics in a contract and hence rendering their contracts highly incomplete and more subject to contract enforcement and export risk (Berkowitz et al., 2006). This increases both the exporters risk of not receiving payment and the importers risk of receiving an inadequate shipment. The complexity of more differentiated products not only makes their quality uncertain to the buyer (Ranjan and Lee, 2007), but it also increases the probability that a dispute between exporter and importer arises, delaying the settlement. Finally, and as argued by Nunn (2007), more complex goods involve higher levels of customization and relationship-specific investments. All these factors make trade of more differentiated or complex products more sensitive to contract enforcement and export risk. ${ }^{7}$

To conduct our analysis based on differentiated products, we first compute total exports of homogeneous, reference, and differentiated goods for each country pair based on the classification of Rauch (1999), and we repeat our baseline regression analysis separately for each goods category. We find that bank linkages matter only for reference and differentiated goods; there is no effect for homogeneous goods. For differentiated goods, the estimated effect of having bank linkages is twice as large as what we estimate for reference goods. Next, we estimate the regressions at the countrypair-year-industry level. For these regressions, we can include country-pair-year and industry fixed effects, which would absorb anything that varies over time by country-pair, including bank linkages. However, we can still identify the differential effect of bank linkages in different categories of goods. In this setting we also find that, relative to homogeneous goods, bank linkages matter more for reference goods and even more for differentiated goods.

Overall, we provide ample evidence that the effect of bank linkages on trade likely works through the amelioration of export risk. All our tests show that bank linkages are more important for trade whenever the export risk is likely to be higher. To rule out that our findings are driven by endogeneity of bank linkages, we demonstrate that formation of new bank linkages for a given

\footnotetext{
${ }^{6}$ Rauch (1999) defines differentiated products as those for which trade is not based on reference prices, where these prices can be quoted either in organized exchanges or in trade publications. As highlighted by Rauch and Trinidade (2002), goods that possess reference prices are sufficiently homogeneous such that prices convey all relevant information for international trade; this is not the case for more differentiated goods which lack reference prices.

${ }^{7}$ Indeed, Hoefele and $\mathrm{Yu}$ (ming) find that cross-border trade in more complex goods exhibit larger shares of cash-in-advance forms of payments relative to less complex industries.
} 
country pair creates trade diversion from countries which compete with the destination country for similar imports.

One avenue by which bank linkages can reduce export risk is through the provision of letters of credit or documentary collections, as discussed in a series of recent papers (Niepmann and SchmidtEisenlohr, 2013; Olsen, 2013; Antràs and Foley, 2015). Letters of credit are typically issued by a bank in the importer's country and confirmed by a bank in the exporter's country, making bank linkages particularly important. We test for this channel using data on U.S. exports, the only country for which we can obtain data on banks' letters of credit exposures. We first document that bank linkages are much more important for U.S. exports than on average in our sample. We then demonstrate that letters of credit are positively associated with new bank linkages. However, not all of the effect of bank linkages on exports is due to the issuance of letters of credit. That is, letters of credit are not the only mechanism by which bank linkages facilitate trade.

Our paper's main contribution is twofold: first, we demonstrate a novel channel though which finance is important for trade; namely, a positive effect of bank linkages that are formed through syndicated loans extended to banks. Second, we demonstrate that this effect is likely due to the reduction of export risk. Because of the richness of our data, we are able to control for countrytime and even for country-pair-time fixed effects and still show that bank linkages are important determinants of trade. In this respect, our paper is contributing to the growing body of literature on the relationship between finance and trade. In addition to the papers showing the importance of actual trade finance and trade guarantees cited earlier, Manova (2008) and Minetti and Zhu (2011) demonstrate the importance of credit constraints for exports. ${ }^{8}$ Recently, Claessens et al. (2015) showed that foreign operations of international banks also play an important role in facilitating trade. $^{9}$

In addition, our paper contributes to an understanding of border effects by showing that various proxies for export risk are associated with lower exports and that such risk is likely reduced through bank linkages between countries. Extant literature has found other avenues of export risk mitigation. For example, Rauch and Trinidade (2002) show the importance of ethnic networks; Guiso et al. (2009) show the role of trust in explaining international trade patterns; and Cristea (2011) and Poole (2012) show the importance of business relations. We add bank linkages formed through bank-to-bank syndicated lending to this list.

\footnotetext{
${ }^{8}$ Paravisini et al. (2011), however, find that in the case of Peru a shortage of credit affects production rather than export-specific activities.

${ }^{9}$ Similarly, in the context of the U.S. Michalski and Ors (2012) shows that bank ownership linkages are associated with inter-state trade.
} 
Moreover, by relating bank linkages to trade, our paper contributes to the literature on the role of financial flows in international business cycles. A more precise understanding of mechanisms through which financial flows affect economic relationships between countries can shed further light on this issue. ${ }^{10}$ Finally, our paper also relates to the more general literature on effects of bank linkages which, not surprisingly after the Global Financial Crisis, focused predominantly on the risk and contagion aspects of bank linkages. ${ }^{11}$ Our paper contributes to this literature by demonstrating that bank linkages also play a positive role in the global economy.

In the next section we present the theoretical background for our analysis. Section 3 discusses the empirical strategy and some identification issues that arise in our analysis. Section 4 describes our data. In Section 5 we present and discuss our main results as well as robustness tests. Section 6 closes with concluding remarks and a brief discussion of the possible mechanisms by which bank linkages may reduce export risks in international trade.

\section{Theoretical Background}

Our empirical analysis fits well in the general framework of the gravity model of trade. To show this, we review the basic microfoundations of the model following the textbook presentation of Feenstra (2004).

Assume that preferences of a representative consumer are isoelastic (CES) and that consumers in each country $j$ consume goods produced in all other countries $i \in[1, C]$ so that the utility function is

$$
U^{j}=\sum_{i=1}^{C} N^{i}\left(c^{i j}\right)^{\frac{\sigma-1}{\sigma}}
$$

where $N^{i}$ is the number of goods produced in country $i$ and $c^{i j}$ is country $j$ 's consumption of goods made in $i$, which also corresponds to the volume of exports from $i$ to $j$, and $\sigma>1$ is the elasticity of substitution. We assume that all goods produced in country $i$ are sold in country $j$ for the same price $p^{i j}$. We also assume balanced trade, which implies that the budget constraint for country $j$

\footnotetext{
${ }^{10}$ While Imbs (2006) shows a positive cross-country correlation between financial flows and business cycle comovements, a recent paper by Kalemli-Ozcan et al. (2013b) finds a negative within correlation.

${ }^{11}$ See, among others, Battiston et al. (2012); Cocco et al. (2009); Craig and von Peter (2014); Delli Gatti et al. (2010); Elliot et al. (2014); Giannetti and Leaven (2012); Haldane and May (2011); Imai and Takarabe (2011); Kalemli-Ozcan et al. (2013a); May and Arinaminpathy (2010); Nier et al. (2007); Sachs (2014) and von Peter (2007).
} 
is given by its total output $Y^{j}$ produced using constant return to scale technology as

$$
Y^{j}=\sum_{i=1}^{C} N^{i} p^{i j} c^{i j}
$$

The optimization yields

$$
c^{i j}=\frac{p^{i j}-\sigma}{P^{j}} \frac{Y^{j}}{P^{j}}
$$

where $P^{j}$ is the CES price index

$$
P^{j}=\left(\sum_{i=1}^{C} N^{i}\left(p^{i j}\right)^{1-\sigma}\right)^{\frac{1}{1-\sigma}} .
$$

The value of exports is then

$$
X^{i j}=N^{i} Y^{j}\left(\frac{p^{i j}}{P^{j}}\right)^{1-\sigma} .
$$

Assuming labor to be the only input and full employment (Krugman, 1979), the zero-profit condition implies that $Y^{i}=y N^{i} p^{i}$, where $y$ is the labor productivity, $N^{i}$ is the labor supply in country $i$ and $p^{i}$ is the price of the domestically produced output in country $i$. Further assume that there is a wedge $T^{i j}$ between the price of the good made in country $i$ sold domestically, $p^{i}$, and the same good sold in country $j, p^{i j}=T^{i j} p^{i}$, with $T^{i i}=1, T^{i j}>1$.

Combining all of the above, we can express the value of exports from $i$ to $j$ in each period $t$ as

$$
X_{t}^{i j}=\frac{Y_{t}^{i} Y_{t}^{j}}{\left(p_{t}^{i}\right)^{\sigma} y}\left(\frac{T_{t}^{i j}}{P_{t}^{j}}\right)^{1-\sigma} .
$$

The wedge $T^{i j}$ between domestic and foreign prices has been given many interpretations in the literature, including transportation costs, trade barriers, and information costs. Here, we will focus on what we believe are two important components: geographical distance and export risk that may arise from asymmetric information and institutional factors that complicate payment enforcement. Our specific interpretation of export risk is related to the cost of payment or contract enforcement in cross-border deals, the importance of which is well documented in Anderson and Marcouiller 
(2002). This cost is likely to be increasing with distance because of longer shipping time, ${ }^{12}$ and it will also be affected by the quality of institutions in country $j$ and by how differentiated the traded good is, which we do not model explicitly. ${ }^{13}$ Further assume that this cost can be reduced if banks in country $i$ are closely linked with banks in country $j$, either through direct payment enforcement and guarantees as in Olsen (2013), through extending letters of credit as in Schmidt-Eisenlohr (2013), or through selection of creditworthy counterparties by banks in country $j$. In particular, Antràs and Foley (2015) and Schmidt-Eisenlohr (2013) show that financial costs take the form of iceberg costs and that banks can reduce them. Thus, we assume

$$
T_{t}^{i j}=D^{i j}\left(R_{t}^{j}\right)^{\left(1-a_{t}^{i j}\right)}
$$

where $D^{i j}$ is constant distance between countries $i$ and $j, R_{t}^{j}$ is the cost of contract enforcement in country $j$ in the absence of bank linkages, and $a_{t}^{i j}$ is the strength of bank linkages between countries $i$ and $j$.

Combining the above and taking logs, we obtain

$$
\begin{aligned}
\ln X_{t}^{i j} & =\ln Y_{t}^{i}+\log Y_{t}^{j}-(\sigma-1) \ln D^{i j}-(\sigma-1) \ln R_{t}^{j} \\
& +(\sigma-1) \ln R_{t}^{j} a_{t}^{i j}-\sigma \ln p_{t}^{i}-\ln y+(\sigma-1) \ln P_{t}^{j}
\end{aligned}
$$

From this equation we can draw two main testable implications with respect to bank linkages:

1. exports are an increasing function of bank linkages $a_{t}^{i j}$, and

2. the effect of bank linkages is stronger the higher the export risk in country $j, R_{t}^{j}$.

In what follows, we will test these two predictions.

\footnotetext{
${ }^{12}$ Antràs and Foley (2015) and Niepmann and Schmidt-Eisenlohr (2013) show that cash-in-advance or letter of credit, both of which are used as remedies for higher export risk, are more likely to be used for longer distance trade. Schmidt-Eisenlohr (2013) presents a model which rationalizes this result.

${ }^{13}$ As explained in the introduction, more differentiated products may be more subject to contract enforcement and export risk because of their complexity and hence incompleteness of their contracts (Berkowitz et al., 2006), or because buyers face larger uncertainty about their quality (Ranjan and Lee, 2007).
} 


\section{Empirical Gravity Model with Export Risk}

The empirical gravity model is a direct application of the equations derived in the theoretical discussion. For our benchmark model, we estimate the following equation:

$$
e x_{i j t}=\alpha+\beta a l_{i j t-1}+G V_{i t}^{\prime} \delta_{1}+G V_{j t}^{\prime} \delta_{2}+G C_{i j}^{\prime} \gamma+\varepsilon_{i j t},
$$

where $e x$ is a log of exports, al is the measure of newly formed bank linkages, described below in Section 4, vector $G V$ (i.e., gravity variables) includes GDP per capita, population in both countries, vector $G C$ (i.e., gravity constant variables) includes time-invariant country-pair gravity variables such as distance between countries' capitals, indicator of whether the countries are contiguous, have common language, and whether they share colonial past. We vary $\alpha$ from being a constant to a vector of fixed effects: $t, i, j$, to $i j$, it, and $j t$ for a fully saturated model. In the regressions at the industry level we also include $i j t$ fixed effects. Our benchmark specification is a fully saturated model where the effects of all controls listed above are absorbed by fixed effects:

$$
e x_{i j t}=\alpha_{i j}+\alpha_{i t}+\alpha_{j t}+\beta a l_{i j t-1}+\varepsilon_{i j t},
$$

with $\beta$ being our coefficient of interest, which we expect to be positive. Note that we include changes in our aggregate bank proximity measures lagged by one year. Thus, we test how new connections formed between banks in year $t-1$ affect trade in year $t{ }^{14}$

As shown in the theoretical discussion, if our hypothesis of bank linkages mitigating export risk is correct, the effect of bank linkages will vary with the export risk of country $j$. We first separate countries into OECD and non-OECD as a rough measure of contract enforcement and estimate our main specification for the four country-pair types.

Next, we extend our analysis, estimating the model:

$$
e x_{i j t}=\alpha_{i j}+\alpha_{i t}+\alpha_{j t}+\beta_{1} a l_{i j t-1}+\beta_{2} R_{i t} a l_{i j t-1}+\beta_{3} R_{j t} a l_{i j t-1}+\varepsilon_{i j t},
$$

where $R_{i t}$ and $R_{j t}$ are proxies for risk of exporting to $i$ and $j$, with their main effects absorbed by $\alpha_{i t}$ and $\alpha_{j t}$. We use ICRG and S\&P country ratings as well as export insurance premia as proxies for export risk. We expect both $\beta_{1}$ and $\beta_{3}$ to be positive, while we expect $\beta_{2}$ to be zero since there should be no effect of risk of exporting to $i$ on exports from $i$ to $j$. We include this measure,

\footnotetext{
${ }^{14}$ We also tested whether bank linkages formed by lending from $j$ to $i$ affect exports from $i$ to $j$ and found no effects.
} 
however, as a placebo test.

As explained before, we also build on the insight that trade in more differentiated goods is expected to be subject to heightened export risk because the enforcement of contracts in these goods is more difficult (Berkowitz et al., 2006; Nunn, 2007; Ranjan and Lee, 2007). Thus, we expect the effect of bank linkages to be higher for more differentiated goods. We, therefore, estimate the model separately for exports of homogeneous and differentiated goods, expecting coefficient $\beta$ to be higher for differentiated goods.

In addition, we estimate a specification with $i j t$ fixed effects using the data disaggregated at SITC-4 level. For each industry $k$ we measure exports from $i$ to $j$ in year $t$. Since the main effect of bank linkages in this regression is absorbed by the fixed effect, we estimate the effect of the interaction between the index of how differentiated the goods are $\left(D_{k}\right)$ and our measure of bank linkages. We expect bank linkages to matter more for more differentiated goods, that is, we expect $\beta$ to be positive in the following model that includes $i j t$ fixed effects:

$$
e x_{k i j t}=\alpha_{i j t}+\alpha_{k}+\beta D_{k} a l_{i j t-1}+\varepsilon_{i j t} .
$$

We conduct additional analysis and several robustness tests, which are described later in the paper.

\section{Data}

To test the hypotheses outlined above we collect data on international trade flows, construct a measure of bank linkages using data on banks' syndicated loans market, and use several proxies for export risk, described in this section. To control for country-level variables in our gravity set up, we use data on GDP and population from the IMF's World Economic Outlook database, and use standard gravity-model variables, such as distance, colonial ties, common language and geographic size, from Head and Mayer (2013) (obtained through the website of CEPII).

\subsection{International Trade}

As measure of bilateral exports from country $i$ to country $j$, we use reported imports by country $j$ from country $i$ in the UN-COMTRADE database. By privileging the importer's reports, instead of the exporter's, we follow Feenstra et al. (2005) and assume that the former are more accurate than the latter. We use the line "S2-TOTAL" as reported in nominal USD. We then deflate these 
values by the U.S. CPI (obtained from the U.S. Bureau of Labor Statistics). Our analytic trade data sample is a balanced panel consisting of 66 countries for the period of 1990-2013 at an annual frequency. See Figure 1 for the list of countries in the sample. We conduct our analysis by applying the following logarithmic transformation to the data:

$$
e x_{i j}=\log \left(1+E X_{i j}\right)
$$

which allows us to preserve the zeros. Out of $102,960=66 \times 65 \times 24$ observations in the period 1990-2013, only 10,403, or 10 percent, are zeros. In more recent years, the zeros in our data compose a smaller proportion of observations for a given year. As shown in Figure A.1 in the Appendix, the proportion of zeros in our data went from 19 percent in 1995 to less than 1 percent in 2010. So, while there is a small mass of country pairs with no trade, especially in the early part of our sample, it is not large enough to influence our results ${ }^{15}$

We also use COMTRADE to obtain industry-level trade data at the 4-digit SITC (Rev.2) level of aggregation. We pair these data with the Rauch (1999) index of product differentiation. ${ }^{16}$ These classification sorts SITC codes into three categories of goods: those traded on international exchanges, those with reference prices-both considered homogeneous goods, and differentiated goods for which branding information precludes them from being traded on exchanges or reference priced.

\subsection{Bank Linkages}

We obtain deal-level data on syndicated international and domestic bank loans from Dealogic's Loan Analytics database (previously known as Loanware). ${ }^{17}$ As our goal is to capture bank-tobank lending activity, we obtain data on all loans extended to public and private sector banks between January 1, 1990 and December 31, 2014. There are three main reasons why we use these data: first, syndicated loans, as opposed to overnight loans, have a long maturity (median maturity in our data is about 3.5 years) and therefore are likely to establish relationships between borrowers and lenders; ${ }^{18}$ second, unlike most bilateral loans, syndicated loans are large and are therefore

\footnotetext{
${ }^{15}$ In the robustness tests section we show that all results in the paper hold if we exclude country pairs without trade.

${ }^{16}$ We obtained the goods classification from Rauch's website: http://econweb.ucsd.edu/ jrauch/rauch_ classification.html.

${ }^{17}$ See Miller and Chew (2011) for the detailed description of syndicated loan market.

${ }^{18}$ In fact, anecdotal evidence suggests that establishing relationships is one of the main purposes of bank-to-bank syndicated lending on some occasions (see e.g., the media coverage of a syndicated loan to Turkish Garanti Bank in 2010, such as "Banks on Parade," IFR Turkey 2010.)
} 
likely to necessitate substantial amount of information acquisition by lenders; third, international syndicated loan markets are large and active, and data are readily available on a consistent basis across many countries. ${ }^{19}$

Ideally, we would like to ensure that each of the loans in our sample is a bank-to-bank loan, but the Dealogic database only allows us to identify borrower type (which we constrain to be either public or private sector bank); it does not allow us to place the same constraints on lenders. ${ }^{20}$ Among the loans in our sample, over 60 percent are term credit, with the rest being revolving loans, CDs, and various credit facilities. We replicate syndicated loans as many times as there are lenders in the syndicate on the signing date of the loan. We link each banking entity to a country on a locational basis. ${ }^{21}$

We represent these loans as a network. The vertices (nodes) of our network, each representing a bank, are indexed by $m=1, \ldots, I$. The edges (direct connections) between each pair of nodes $m$ and $n$, loans in our case, are denoted by $c_{m n}$, which is binary $\{0,1\}$. Not every pair of nodes is connected by edges. The edges are directed so that $c_{m n} \neq c_{n m}$. We will denote $c_{m n}$ as connections going from node $m$ to node $n$, i.e., a link generated by bank $m$ lending to bank $n$. We will refer to $c_{n m}$ as bank linkages.

For each of the years in our sample, we construct a cumulative global banking network (GBN), where for each year $t$ all loans between 1990 and $t$ are included. ${ }^{22}$ Thus, cumulative GBN expands

\footnotetext{
${ }^{19}$ Cerutti et al. (2015) discuss in detail the importance of syndicated loan market and show that the share of syndicated loans rose to as much as 30 percent of total cross-border bank lending in recent years. Moreover, according to Ivashina and Scharfstein (2010) over the last 30 years the syndicated loans market has evolved into a key vehicle through which banks lend to large corporations. Similarly, De Haas and Van Horen (2012) report that international syndicated loans made up 40 percent of all cross-border funding to firms in the U.S. and more than two thirds of cross-border flows to emerging markets in 2007. The interbank portion of this market is also large and active. In the late 1990s, syndicated bank loans extended to banks and reported in Loan Analytics amounted to over 30 percent of total bank claims on banks as reported by the BIS. This ratio fell to below 20 percent by the end of our sample as interbank lending ballooned prior to the global financial crisis. In 2007 alone 4.7, trillion USD worth of syndicated loans extended to banks are reported in Loan Analytics.

${ }^{20}$ Some of the lenders within a syndicate may not be banks. Upon detailed review of the lenders' names, we find that the non-bank lenders account for roughly 29 percent of all lenders in our sample and consist mostly of insurance companies and special purpose vehicles. We kept them in our sample because there was no way to systematically exclude them. The only way to limit the loans to those issued only by banks is to only consider term loans type A (Cerutti et al., 2015), which constitute less than 5 percent of the sample. We reconstructed the linkages measure using this limited list of loans and re-estimated our regressions. We find that the effect of this definition of linkages is about half the size of the our main results. For our benchmark specification of column (8) in Table 1, the corresponding coefficient is 0.047 with a $\mathrm{P}$-value of 0.13 .

${ }^{21}$ Mian (2006) shows that cultural and geographical distances between headquarters and local branches play an important role in lending practices.

${ }^{22}$ While Dealogic's data extends back to 1980, the loan coverage is substantially limited before 1990. The resulting network would be expanding due to expanding coverage, not increasing connectivity.
} 
every year through the addition of new connections as loans between bank pairs that have not engaged in lending previously. We rely on this cumulative network to measure the extent of newly formed bank linkages. By the end of our sample, we have 3393 banking institutions as lenders and 6018 banking institutions as borrowers. ${ }^{23}$

We compute a measure of bank linkages that only takes into account direct connections with all other connections set to 0 . We refer to this measure as the aggregate number of linkages $A L_{i j}$, and it is simply the sum of bank pairs in countries $i$ and $j$ that are directly connected. We use the log transformation of the one-period change in the aggregate number of linkages, which is the logarithm of a number of new connections formed between countries $i$ and $j$ :

$$
a l_{i j t}=\log \left(1+\left(A L_{i j t}-A L_{i j t-1}\right)\right) .
$$

This one-period change measures the increase in number of linkages that is due to new connections that were formed in year $t$. In our regressions we use the first lag of this variable to measure the effect of new bank linkages formed between years $t-2$ and $t-1$ on exports in year $t{ }^{24}$ The distribution of bank linkages over years, over lenders, and over borrowers is shown in Figure 1. Appendix Table A.3 provides summary statistics for the measure of bank linkages as well as its components.

\subsection{Export Risk}

We employ various proxies for export risk. Summary statistics for all these measures are reported in Appendix Table A.3.

Our first three proxies are general country risk measures. The first is the International Country Risk Guide (ICRG) index of political risk. This index has 12 components aimed at assessing the political stability of a country. ${ }^{25}$ We do not have a prior on which of the components of the ICRG index would be the best proxy for the quality of contract enforcement in a given country. All of these components are highly correlated and would be difficult to interpret if included individually. For these reasons, we compute the first principle component, which explains 45 percent of variance in all the components for our sample and use this first principle component as a proxy for contract

\footnotetext{
${ }^{23}$ We employ Stata Graph Library by Miura (2011) for network construction. For further detail see Hale (2012).

${ }^{24}$ We experimented with bank linkages from $j$ to $i$ and with higher order connections, but found that only direct linkages from $i$ to $j$ have an impact on exports from $i$ to $j$.

${ }^{25}$ The components of ICRG's political risk index are described in Table A.4 in the Appendix. The components measure different aspects of political risk, ranging from government stability to risks to international investors.
} 
enforcement quality. ${ }^{26}$ Higher values of this measure indicate lower country risk. We expect that a sovereign's ability to repay its debts is correlated with payment enforcement costs, so the second measure we use is the sovereign credit rating histories from Standard and Poors (S\&P). The S\&P credit rating is alphabetical, but we assign numerical values to the ratings - with higher values indicating worse rating, or higher risk. ${ }^{27}$ The third measure is even more crude-we split our sample into OECD and non-OECD countries, since OECD membership tends to be correlated with lower business risk environment. ${ }^{28}$

We also use a measure that is directly related to export insurance: export insurance cost measured as export insurance premia, obtained from the U.S. EXIM Bank. Per our request, the EXIM Bank compiled average insurance premia they charged on export insurance contracts by destination country, including the United States, for all the years in our sample. For the United States, data are only available starting in 1996.

Our final measure is at the industry level. The existing literature suggests that export risks are higher for goods that are more differentiated (Berkowitz et al., 2006; Nunn, 2007; Ranjan and Lee, 2007). If bank linkages help reduce export risk, this implies that for more differentiated goods the effects of bank linkages will be larger, as there are more risks to mitigate. We thus use the Rauch (1999) classification of industries into those with homogeneous, reference, and differentiated goods.

\section{$5 \quad$ Effects of Bank Linkages on Exports}

Our benchmark results are presented in Table 1, where we test whether changes in our measure of new bank linkages formed during year $t-1$ affect exports in year $t$. In column (1) we include all common gravity regressors, but no fixed effects. ${ }^{29}$ We find a positive correlation between newly

\footnotetext{
${ }^{26}$ We computed first three principal components (PC) for the 12 index components, those with eigenvalues over one, and found that only the first PC is useful for our analysis. The first PC loads positively on all the index components with loadings ranging from 0.12 on government stability to 0.37 for military in politics. The loading on investment profile, subcomponent of which is used in Antràs and Foley (2015), is 0.23. The first PC explains 45 percent of all variance and has eigenvalue of 5.3, while next component only explains additional 12 percent and has eigenvalue of 1.5 .

${ }^{27}$ We assign value of 1 for AAA + rating, 2 to AAA rating, etc. Our results are robust to alternative codifications.

${ }^{28}$ We categorize as OECD countries only the 23 high-income economies that where members of this organization by 1990. All other current OECD members in our sample are categorized as non-OECD countries.

${ }^{29}$ In all regressions the estimating period is 1990-2013. Given that bank linkages enter lagged in the model, there a total of $98,670=66 \times 65 \times 23$ possible observations. The actual number of country pairs in the data, however, is only 93,930 because there are countries in the sample that didn't become independent before 1990. In addition, there are some countries with no GDP or population data available for some of the early years. Thus, the regressions with those covariates are based on a smaller total number of obseravations.
} 
formed bank linkages and the following year's exports. ${ }^{30}$ Of course, this correlation might be due to globalization trends. Therefore, in column (3), we add time fixed effects. We find that the correlation is somewhat diminished, but is still positive and statistically significant. We worry, however, that the correlation can be explained by historically established country ties; therefore, we include country $i$ and country $j$ fixed effects in column (4) and (5), with and without year fixed effects. We find that the effect of bank linkages still remains statistically significant, although it is slightly smaller.

Time-invariant ties between countries, however, are better captured with country-pair fixed effects. We add this pair fixed effects in columns (6) and (7) of Table 1, with and without time fixed effects, respectively. We find that the within-pair portion of the correlation between newly formed bank linkages and trade in the following year is about half of the total correlation we observed in the previous columns. Nevertheless, it remains statistically significant.

An important potential source of spurious correlation is general economic and financial conditions in each country. Hale (2012) shows that bank linkages are less likely to form if a country is experiencing a recession or a banking crisis. Clearly, these conditions can also affect exports as well as imports. Thus, in column (8) we estimate a fully saturated model, that is, we include countrypair, source-country-time, and destination-country-time fixed effects. These fixed effects capture any time-invariant country-pair characteristics that could lead to both higher trade volumes and more bank linkages between these countries as well as any time-varying country-specific dynamics that could account for target countries attracting both trade and bank lending and for source countries exporting both goods and bank funds. We find that the effect of bank linkages on trade remains positive and statistically significant, although it is further diminished. It remains statistically significant when we double-cluster standard errors on source and target countries as shown in column (9).

Since all variables are in logs in the regressions, it is easy to interpret the magnitudes of the coefficients. Our most conservative results - those in columns (8) and (9)-suggest that doubling the change in intensity of bank linkages due to new banking connections is associated with a 7 percent increase in exports in the following year; this impact is not very large, but it is not negligible either. In other words, when banks in country $i$ extend loans to twice as many banks with whom they previously did not have a relationship in country $j$ as in country $k$, other things being equal, exports from $i$ to $j$ increase in the following year by 7 percent more than exports

\footnotetext{
${ }^{30}$ We test for potential specification problems by estimating a Poisson pseudo-maximum-likelihood model following Santos Silva and Tenreyro (2006) and Santos Silva and Tenreyro (2010). We find that the results are very similar to the OLS specification, with coefficient on bank linkages equal to 0.08 and significant at 1 percent level even when we cluster standard errors on country-pairs.
} 
from $i$ to $k$. Given that the standard deviation of newly formed linkages is almost four times its mean, as reported in Appendix Table A.3, doubling the change in intensity of bank linkages is not an unreasonable thought experiment. Note also that this is likely to be a lower bound on the effect of bank linkages on trade for three reasons: first, our measure captures only a subset of bank relationships (those through the syndicated loan market); second, some of the true effect is absorbed along with the spurious correlation by fixed effects included in the regressions; and third, some of the effects may manifest at longer time horizons than the one year lag effect we measure.

To explore the mechanism behind this correlation, we next test our hypothesis that bank linkages influence exports by reducing export risks associated with payment enforcement and other problems arising from information asymmetries.

\subsection{Export Risk and Bank Linkages}

In this section, we test our hypothesis that the mechanism through which bank linkages affect exports is related to export risk. All regressions that follow include the full set of fixed effects (country-pair, source-country-time, and destination-country-time), unless stated otherwise.

One implication of the export risk reduction mechanism is that bank linkages should be more important for countries in which contract enforcement institutions are generally worse. We use two rather widely used measures of country risk - ICRG indexes and S\&P sovereign credit ratings. These measures do not necessarily reflect export risk directly, but are widely accepted measures of overall contract enforcement and creditworthiness of the countries, so we expect them to be positively correlated with export risk. Because main effects of country risk variables are absorbed by country-time fixed effects, we only include lagged change in bank linkages as well as interactions of these changes with risk measures for source and target countries. The results are reported in columns (1) and (2) of Table 2, for ICRG index and sovereign credit rating, respectively.

We find that higher country risk (lower ICRG index or higher S\&P risk measure) of the importer, country $j$, makes bank linkages more important for trade. This is consistent with our hypothesis-if bank linkages help alleviate export risk, they will have higher impact on exports to countries with higher risk. In fact, for exports to countries with good credit rating or high ICRG score, bank linkages don't matter at all. Specifically, F-tests show that for countries with ICRG index slightly above average and higher as well as for countries with sovereign credit rating better than $\mathrm{A}+$, there is no statistical effect of bank linkages on trade. In contrast, bank linkages matter twice as much as for the full sample if the ICRG score is two standard deviations below the mean or if the credit rating is worse than BBB-. As expected, country risk measure of the exporter does not affect the 
importance of bank linkages for trade. These results are consistent with the papers by Olsen (2013) and Niepmann and Schmidt-Eisenlohr (2013), which find that only importer's risk characteristics matter for international trade.

We next turn to more direct measures of export risk. In column (3) of Table 2 we include interactions of export insurance premium (cost of export insurance) with our measure of bank linkages. Data on export insurance premia were obtained from the U.S. EXIM bank and are average premiums charged on actual export insurance contracts. We expect that higher premia are associated with higher export risk and therefore will make bank linkages more important. Our sample is reduced substantially here because export insurance premia are only available for a limited number of countries. In preliminary tests, we learned that, as expected, insurance premia of exporters do not matter. In order to maximize the set of country pairs in our analysis, we exclude this variable. We find, consistent with our previous analysis, that higher risk of the importers is associated with a bigger role of bank linkages in trade. F-tests show that bank linkages have a statistically significant effect on exports to countries where export premia exceed the average by more than 0.86 of standard deviation.

We then follow the simple approach of splitting importers and exporters into groups by OECD membership, since by all measures of the rule of law, contract enforcement and the like, OECD countries score on average much better than non-OECD countries (Hall and Jones, 1999; Rodrik et al., 2004). The results are presented in Table 3. We find that bank linkages are only important for exports to non-OECD countries and are twice as important for country pairs in which the exporter is also a non-OECD country, compared to pairs in which exporter is an OECD country. ${ }^{31}$

As previously discussed, the existing literature suggests that export risks are higher for goods that are more differentiated (Berkowitz et al., 2006; Nunn, 2007; Ranjan and Lee, 2007). If bank linkages help reduce export risk, this implies that for more differentiated goods the effects of bank linkages will be larger because there are more risks to mitigate. We test this hypothesis by estimating our benchmark regressions for exports of differentiated, exchange-traded, and reference-priced goods, using COMTRADE data at the 4-digit SITC level sorted into Rauch (1999) categories.

The results are presented in Table 4. We find that the coefficient on bank linkages is small and marginally statistically significant for homogeneous goods traded on exchanges. For reference goods (goods with prices listed in reference catalogues), the effect is twice as large, and for for differentiated

\footnotetext{
${ }^{31}$ Another proxy for contract enforcement could be a legal origin of a country - that is common vs. civil law. Antràs and Foley (2015) show that in countries with legal origin other than common law cash-in-advance is more likely to be used. Consistent with their result, we find that bank linkages matter more for both exporters and importers from common law countries, countries which are more likely to rely on bank services for their international trade, but this is only the case for country pairs with both exporters and importers classified as OECD countries.
} 
goods it twice as large as for reference goods. Thus, bank linkages are more important for exports of differentiated goods, which is consistent with the interpretations of our results as bank linkages reducing export risk. ${ }^{32}$

All the above results are consistent with the mechanism we proposed: bank linkages contribute to trade growth by reducing export risk. While they do not prove that the effect of bank linkages on trade is causal, one would be hard pressed to find an alternative story that would be consistent with all the evidence presented. Nevertheless, we are concerned about country-pair dynamics that could lead to both, growing trade and acceleration in the formation of bank linkages. Trade data, disaggregated by industry, allow us to address this concern.

In Table 5 we present the results of the regressions where the dependent variable is exports from country $i$ to country $j$ of industry $k$ goods in year $t$. We control for industry and country-pair-year fixed effects, which absorb any time-varying country-pair variables including our measure of changes in bank linkages. Our variable of interest is an interaction between change in bank linkages and indicators of differentiated and reference goods (homogeneous goods being a baseline category). We find, consistent with our hypothesis and with results in Table 4, that bank linkages matter significantly more for trade in reference and differentiated goods than for homogeneous goods, and that the effect is larger for differentiated goods. These effects are statistically significant whether we cluster standard errors on country pairs or double cluster them on both source and target countries.

Tying these findings together, we find strong support for our conjecture that bank linkages increase exports by reducing export risk. Six separate tests of the mechanism point towards this conclusion. We rule out the possibility of common factors driving the correlation between bank linkages and trade by finding different effect of bank linkages for different categories of goods in the regression with country-pair-year fixed effects.

The only remaining concern that would preclude us from claiming a causal effect of bank linkages on trade is that of reverse causality. Grosse and Goldberg (1991) asserted that banks may follow their clients to other countries. Seth et al. (1998), however, found that the "follow the customer" hypothesis had limited empirical support. Be it as it may, if somehow new bank linkages are formed in anticipation of trade increase in differentiated good industries, the causality of our findings would appear to go in the other direction. We believe that this indeed may be the case, but the reason for bank linkages to form in anticipation of trade would be exactly the mechanism we describe in the paper - to facilitate trade and provide ways to alleviate export risk. Thus, we are quite convinced that our evidence shows that bank linkages help reduce export risk and thereby increase trade

\footnotetext{
$\overline{{ }^{32} \text { We must note that exports of differentiated goods }}$ might also involve higher upfront expenses and therefore require more bank funding, which would be an additional mechanism through which bank linkages may affect trade.
} 
volume.

We do, however, conduct an additional test that demonstrates that our results are not driven by endogeneity. If formation of bank linkages indeed increases exports from $i$ to $j$, it is unlikely that this increase is entirely due to trade creation - some of it has to be trade diversion. Thus, we should observe a decline in exports from $i$ to countries that import similar set of goods from $i$. Our story, therefore, implies a decline in exports from $i$ to $k$ in response to new bank linkages formed between $i$ and $j$, where $i j$ and $i k$ pairs have similar trade composition. Importantly, bank linkages between $i$ and $j$ are exogenous to exports from $i$ to $k$.

To conduct this test, we find a destination country $k$ for each country pair $i j$ in each year, so that exports from $i$ to $k$ closely match the 4-digit industry composition of exports from $i$ to $j$. To do this, we rank industries by volume of exports for each country pair and year, compute the rank correlation, and pick the country pair with the highest correlation to $i j$ in a given year. We then drop observations in which the highest correlation was below 0.4 (about 15 percent of the sample). We then estimate the following regression:

$$
e x_{i k t}=\alpha_{i j}+\alpha_{i t}+\alpha_{j t}+\beta a l_{i j t-1}+\varepsilon_{i j t},
$$

where we expect coefficient $\beta$ to be negative. Table 6 shows that this is indeed the case. The formation of new bank linkages between countries $i$ and $j$ reduces exports from $i$ to a country that has most similar industrial composition of imports from $i$. Thus, we demonstrate that our results are not driven by potential endogeneity.

\subsection{Further evidence for the mechanism}

One of the way in which bank linkages may help reduce export risk is by facilitating the issuance and underwriting of the Letters of Credit. As described in detail in Niepmann and Schmidt-Eisenlohr (2013), Letters of Credit provide insurance for trade transactions and the use of Letters of Credit is associated with export risk. Using the data on foreign transactions of the U.S. foreign banks available through form FFIEC 009a we compute total Letter of Credit (LC) exposure of U.S. banks vis-à-vis other countries for years 1991-2013, measured in real U.S. dollars. We then test whether our measure of newly formed bank linkages is indeed associated with increase in these exposures and whether these in turn affect U.S. exports. Since the data are only available for the U.S. banks, this part of our analysis is limited to bank linkages formed by U.S. banks lending to foreign banks and U.S. exports. The unit of observation is now target country-year, so we can only control for year and target country fixed effects. 
We begin by demonstrating that the effect of bank linkages on trade is still present in this restricted sample, and is in fact substantially larger, as shown in column (1) of Table 7. We next show, as has been established in the literature, that there is a contemporaneous correlation between the use of Letters of Credit and exports from U.S, as shown in column (2): doubling the Letter of Credit exposure is associated with 27 percent higher exports.

In column (3) of Table 7, we demonstrate that LC exposures are associated with lagged increase in bank linkages with the elasticity of 19 percent. We construct predicted values for the LC exposures using the results of this regression. In column (4), we show that the portion of the LC exposures that is due to the increase in bank linkages is important in explaining exports - the coefficient on predicted exposures is positive and statistically significant with the coefficient very close to 1 . These results confirm that bank linkages formed through syndicated loan market may lead to higher instance of LC issuance and therefore to more trade.

There are of course other ways through which bank linkages may influence trade, such as facilitating payments, providing information on creditworthiness of counterparty, etc. In fact, when we control for the LC exposures, the effect of change in bank linkages remains positive and statistically significant (although diminished in magnitude - see column (5) of Table 7). These other avenues, however, are not observed to researchers. Thus, the evidence in Table 7 provides support for only a portion of the mechanism by which bank linkages may help increase trade, but together with recent work on Letters of Credit discussed previously, it strongly supports our hypothesis that bank linkages help reduce export risk.

\subsection{Robustness tests}

We conduct two sets of robustness tests on our benchmark specification. ${ }^{33}$ The first set of tests addresses concerns about influential observations and the second set assesses the robustness of our results to the inclusion of country-pair time-varying covariates.

\subsubsection{Influential Observations}

In Table A.1. we provide estimates of our benchmark specification with a modified sample. The most important influential time period is that of the global financial crisis; in 2008-09, banking activity came to a standstill while trade collapsed. A number of papers, in fact, relate this trade

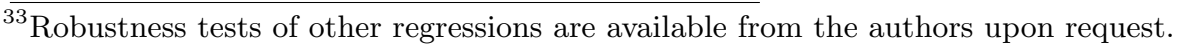


collapse to the lack of access to financing. ${ }^{34}$ To make sure that our results are not entirely driven by this episode, however, we estimate our regression only using the data up to 2007 . We find that the effect of bank linkages on trade is slightly smaller than in the benchmark, but is still positive and statistically significant (see column (1)).

There are also influential countries in our analytic sample. During our sample period, China's trade expanded dramatically as did its financial linkages with the rest of the world. We find, however, that our results are not driven by China, as shown in column (2) of Table A.1. Our results are also not driven by the U.S., the world banker (Gourinchas and Rey, 2007), as shown in column (3). Our benchmark sample includes two offshore centers: Bahamas and Trinidad and Tobago. Column (4) shows that dropping these islands from the sample does not affect our results.

As noted before, our benchmark models are estimated with a strictly balanced panel. When there is no reported trade data between country pairs, the observations are treated as zeros. In column (5) we show that the results are robust to dropping the zeros from the estimation.

Our baseline results are obtained based on imports data from COMTRADE. However, we also run robustness checks using exports data from the IMF's Direction of Trade Statistics database (DOTS), as COMTRADE statistics may have unreported data. ${ }^{35}$ Although, both DOTS and COMTRADE databases are based on underlying statistics reported by national agencies, discrepancies in coverage between the two databases exist. This is due, in part, to the IMF practice of using imputation methods in the DOTS database (see e.g., Hummels and Lugovskyy, 2006). This affects the distribution of observations that are zeros in the two databases. ${ }^{36}$ As column (6) of Table A.1 shows, the results are qualitatively comparable to our benchmark that is based on aggregation of COMTRADE data, although they are smaller in magnitude.

\subsubsection{Including Country-Pair Time-Varying Covariates}

We now assess the stability of our results to the inclusion of additional controls that may explain trade and that vary over time within country pairs. ${ }^{37}$ We first describe the additional data used to conduct these tests; then we present and discuss results.

\footnotetext{
${ }^{34}$ For example, Ahn et al. (2011) demonstrate that financial factors contributed to trade collapse, Amiti and Weinstein (2011) show a causal relationship between health of banks providing trade finance and exports, Chor and Manova (2012) show that trade collapse was more severe for firms with limited access to finance.

${ }^{35}$ DOTS data, unfortunately, are only available at the aggregate level.

${ }^{36}$ Figure A.2 in the Appendix shows the distribution of the DOTS data for different years. It is evident it has less zeros than the UN-COMTRADE data, specially in the early years of our sample period.

${ }^{37}$ All country-time variables are absorbed by country-time fixed effects.
} 


\section{Additional data for robustness tests}

Regional trade agreements, GATT/WTO membership, and common currency. We use data on trade agreements and common currency for years 1990-2006 from Head and Mayer (2013). We complemented the data on regional and bilateral trade agreements and GATT/WTO membership for years 2007-2013 using the World Trade Organization's Regional Trade Agreements Information System (RTA-IS). ${ }^{38}$ We complemented the data on common currency by hand and based on information from the IMF. In our country sample this basically meant to update in the data the year of eurozone membership for countries that adopted the euro after 2006. We also corrected Head and Mayer (2013) data to include the adoption of the U.S. dollar by Ecuador and El Salvador in 1999 and 2000, respectively.

Financial crises. We obtained data on systemic banking crises, currency crises and sovereign debt crises from Laeven and Valencia (2013).

Financial Integration and Financial Flows. We use bilateral data on banks' claims on all sectors from BIS locational banking statistics including all types of claims. BIS reports both stocks and valuation-adjusted flows of these variables, for both assets and liabilities. We use stocks of claims outstanding, in real USD, to represent the degree of financial integration between the countries in the pair. We use flows of bank credit to proxy for financial flows. Since trade credit extended by banks to firms is frequently backed up by credit lines the banks obtain from larger financial institutions, flows of bank claims also provide a proxy for the availability of trade credit.

There are many missing values in the BIS series for the 812 country-pairs we have in the data. We replaced, when possible, missing values of assets of $i$ in $j$ with the reported value of liabilities of $j$ to $i$, for both stocks and flows. In addition, some stocks of claims are negative. We replaced both remaining missing values of stocks and flows and negative values of stocks with zeros. In our view, small claims of stocks are more likely to be missing, thus we claim that zero is a reasonable approximation in these cases. As a result, stock and flow measures are zero for about 5,000 of 16,240 observations, with a larger share of zeros in the first half of the sample.

For the regressions we make the following logarithmic transformation of the stocks $B S_{i j}$

$$
b s_{i j}=\log \left(1+B S_{i j}\right)
$$

\footnotetext{
${ }^{38}$ The RTA-IS system can be accessed through the web, at http://rtais.wto.org/ui/PublicAllRTAList.aspx. We use the list of all regional and bilateral trade agreements in force as of December 2013. Following Head and Mayer (2013), two countries are coded as having an RTA if the two countries belong to a regional trade agreement or if they have a bilateral one. We considered only agreements into force for over six months of the year (thus, RTAs such as Chile-Japan that entered into force in September 2007 are coded as entering into force in 2008).
} 
Since flows $B F_{i j}$ can be negative, we compute

$$
b f_{i j}=\log \left(1+B F_{i j}\right), B F_{i j}>=0 ; \quad b f_{i j}=-\log \left(1-B F_{i j}\right), B F_{i j}<0 .
$$

\section{Results with additional control variables}

The tests that use these data are presented in Table A.2. In column (1) we control for whether both countries $i$ and $j$ are in a regional or bilateral trade agreement. We find that while regional trade agreements do indeed increase trade, controlling for them does not change the impact of bank linkages. In our fully saturated model, we find that common currency does not have a statistically significant impact on trade (column (2)). Most importantly for our purposes, however, we find that controlling for common currency does not change the effect of bank linkages. Similarly, changes in bilateral exchange rate also do not have an effect on trade and controlling for them does not change the effect of bank linkages (column (3)).

While individual countries' crises are controlled for by country-time fixed effects, we can expect dynamics of trade and bank lending to be different if both countries are experiencing the same crisis. In column (4) we control for such situations, separating crises into banking system, debt, and currency crises. We find that a combination of currency crises has a negative effect on trade and that these controls do not alter our findings.

A number of recent papers show the importance of financial linkages in explaining trade (Manova, 2008; Ahn et al., 2011; Antràs and Foley, 2015; Amiti and Weinstein, 2011; Minetti and Zhu, 2011; Chor and Manova, 2012). For this reason, and to ensure that our main results are not driven by financial linkages, we include measures of financial linkages in our gravity regression. In column (5) we include measures of stocks of bank claims to proxy for financial integration, ${ }^{39}$ and flows to proxy for trade credit availability as measured by BIS bank claims of $i$ on $j$ and vice versa and for financial flows that are measured as valuation adjusted changes in these bank claims. We find that controlling for these proxies of financial linkages does not alter our results.

When we include all these controls together (column (6)), with the exception of common currency and exchange rate, which did not have any effect, we continue to find that doubling bank linkages increases trade in the following year by about 6 percent, about half of the magnitude obtained in our benchmark specification. This effect remains statistically significant.

\footnotetext{
${ }^{39}$ Stocks of assets are accumulated over time and are commonly used in the literature as a measure of financial integration — see, for example, Imbs (2006), Kalemli-Ozcan et al. (2013a), and Kalemli-Ozcan et al. (2013b).
} 


\section{Conclusion}

We present evidence that when banks in a given country pair become more closely connected, trade between these two countries tends to increase in the following year by an economically and statistically significant amount. We find this result controlling for gravity variables, financial integration and financial flows, as well as for a full set of fixed effects: exporter-year, importer-year, and country pair. Moreover, we find that bank linkages are more important for exports of more differentiated goods. This result is statistically significant even when we control for export-importer-year fixed effects that absorb all potential factors that might jointly drive dynamics of bank linkages and trade for a given country pair. We conjecture that the mechanism for this effect of bank linkages is related to the role banks play in reducing export risk. We show a variety of tests that support this conjecture and show, in addition, that export payment guarantees that banks provide through letters of credit are indeed one of the ways, but not the only way, in which banks help reduce export risk.

Besides the provision of finance, there are a number of other ways in which banks can alleviate export risk, for which we cannot test given currently available data. Because banks are particularly good at providing information on creditworthiness of potential buyers, they may help reduce information asymmetries that hinder international trade in the way that is similar to social and other information networks. ${ }^{40}$. For example, bank linkages mean better information for banks about contract enforcement in the destination country. This implies that bank linkages result in better information of banks in country $i$ about the probability of banks and firms in country $j$ to honor financial contracts, better information about the value of collateral in country $j$, and knowledge of the best ways to seize collateral and assure payment in country $j$. All this may result in firms in country $i$ more likely to transact with firms in country $j$, particularly if they can work with country $i$ 's banks that are more familiar with risk levels and risk management in country $j$ (because such banks can offer cheaper finance and/or insurance for exporting to $j$ ). Similarly, the presence of bank linkages between two countries signals a level of trust and reputation between banks from the two countries. Cross-border bank linkages then may result in more international trade by making firms more willing and able to engage in cross-border trade.

These results are important for a number of reasons: first, they show a yet unexplored way in which finance is related to trade; second, the shed light on the mechanism that gives rise to the border effect of trade that is so far not fully understood; third, they provide mechanism which links

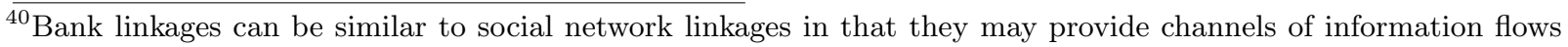
and help match sellers to buyers in different countries. On the importance of social and information networks see the early survey by Rauch (2001) and the recent papers by Combes et al. (2005) and Baston and Silva (2012).
} 
financial integration to real integration; fourth, they demonstrate positive effects of bank linkages that in the wake of the global financial crisis seem to get much less attention in the literature than the dangers of such linkages. 


\section{References}

Ahn, J., Amiti, M., and Weinstein, D. (2011). Trade finance and the great trade collapse. American Economic Review Papers and Proceedings, 101:298-302.

Alessandria, G., Kaboski, J. P., and Midrigan, V. (2011). Us trade and inventory dynamics. American Economic Review, 101(3):303-307.

Amiti, M. and Weinstein, D. (2011). Exports and financial shocks. Quarterly Journal of Economics, 126:1841-187.

Anderson, J. E. and Marcouiller, D. (2002). Insecurity and the pattern of trade: an empirical investigation. Review of Economics and Statistics, 84(2):342-352.

Antràs, P. and Foley, F. C. (2015). Poultry in motion: A study of international trade finance practices. Journal of Political Economy, 123:853-901.

Baston, P. and Silva, J. (2012). Networks, firms, and trade. Journal of International Economics, $87(2): 352-364$.

Battiston, S., Delli Gatti, D., Gallegati, M., Greenwald, B. C., and Stiglitz, J. E. (2012). Liaisons dangereuses: Increasing connectivity, risk sharing, and systemic risk. Journal of Economic Dynamics and Control, 36(8):1121-1141.

Bems, R., Johnson, R. C., and Yi, K.-M. (2013). The great trade collapse. Annual Review of Economics, 5(1):375-400.

Berkowitz, D., Moenius, J., and Pistor, K. (2006). Trade, law, and product complexity. The Review of Economics and Statistics, 88(2):363-373.

Cerutti, E., Hale, G., and Minoiu, C. (2015). Financial crises and the composition of cross-border lending. Journal of International Money and Finance, 52:60-81.

Chor, D. and Manova, K. (2012). Off the cliff and back? Credit conditions and international trade during the global financial crisis. Journal of International Economics, 87:117-133.

Claessens, S., Hassib, O., and van Horen, N. (2015). The role of foreign banks in trade. mimeo available at

http://www.dnb.nl/en/binaries/Trade\%20and\%20Foreign\%20Banks\%20-\%20Mar\%202015_tcm47-322887. 
Cocco, J. a. F., Gomes, F. J., and Martins, N. C. (2009). Lending relationships in the interbank market. Journal of Financial Intermediation, 18:24-48.

Combes, P.-P., Lafourcade, M., and Mayer, T. (2005). The trade-creating effects of business and social networks: Evidence from France. Journal of International Economics, 66(1):1-29.

Contessi, S. and de Nicola, F. (2012). What do we know about the relationship between access to finance and international trade. Federal Reserve Bank of St.Louis WP 2012-054B.

Craig, B. and von Peter, G. (2014). Interbank tiering and money center banks. Journal of Financial Intermediation, 23(2):322-347.

Cristea, A. D. (2011). Buyer-seller relationships in international trade: Evidence from U.S. states' exports and business-class travel. Journal of International Economics, 84(2):207-220.

De Haas, R. and Van Horen, N. (2012). International shock transmission after the lehman brothers collapse: Evidence from syndicated lending. The American Economic Review, 102(3):231-237.

Delli Gatti, D., Gallegati, M., Greenwald, B., Russo, A., and Stiglitz, J. E. (2010). The financial accelerator in an evolving credit network. Journal of Economic Dynamics and Control, $34(9): 1627-50$.

Elliot, M., Goluby, B., and Jackson, M. O. (2014). Financial networks and contagion. American Economic Review, 104:3115-53.

Feenstra, R. C. (2004). Advanced International Trade: Theory and Evidence. Princeton University Press, Princeton, New Jersey.

Feenstra, R. C., Lipsey, R. E., Deng, H., Ma, A. C., and Mo, H. (2005). World trade flows: 1962-2000. Working Paper 11040, National Bureau of Economic Research.

Garratt, R., Mahadeva, L., and Svirydzenka, K. (2011). Mapping systemic risk in the international banking network. Bank of England Working Paper 413.

Giannetti, M. and Leaven, L. (2012). The flight home effect: Evidence from the syndicated loan market during financial crises. Journal of Financial Economics, 104(1):23-43.

Gourinchas, P.-O. and Rey, H. (2007). From world banker to world venture capitalist: U.s. external adjustment and the exorbitant privilege. In Clarida, R., editor, G7 Current Account Imbalances: Sustainability and Adjustment, chapter 1, pages 11-66. University of Chicago Press, Chicago, IL. 
Grosse, R. and Goldberg, L. G. (1991). Foreign bank activity in the united states: An analysis by country of origin. Journal of Banking and Finance, 15:1093-1112.

Guiso, L., Sapienza, P., and Zingales, L. (2009). Cultural biases in economic exchange. Quarterly Journal of Economics, 124:1095-1131.

Haldane, A. G. and May, R. M. (2011). Systemic risk in banking ecosystems. Nature, 469:351-355.

Hale, G. (2012). Bank relationships, business cycles, and financial crisis. Journal of International Economics, 88:312-325.

Hall, R. E. and Jones, C. I. (1999). Why do some countries produce so much more output per worker than others? The Quarterly Journal of Economics, 114(1):83-116.

Head, K. and Mayer, T. (2013). Gravity equations: Toolkit, cookbook, workhorse. In Gopinath, G., Helpman, E., and Rogoff, K., editors, Handbook of International Economics, volume 4. Elsevier.

Hoefele, A. Schmidt-Eisenlohr, T. and Yu, Z. (Forthcoming). Payment choice in international trade: Theory and evidence from cross-country firm level data. Canadian Journal of Economics.

Hummels, D. and Lugovskyy, V. (2006). Are matched partner trade statistics a usable measure of transportation costs?*. Review of International Economics, 14(1):69-86.

Imai, M. and Takarabe, S. (2011). Bank integration and transmission of financial shocks: Evidence from Japan. American Economic Journal: Macroeconomics, 3(1):155-83.

Imbs, J. (2006). The real effects of financial integration. Journal of International Economics, $68(2): 296-324$.

Ivashina, V. and Scharfstein, D. (2010). Loan syndication and credit cycles. American Economic Review, 100:57-61.

Kalemli-Ozcan, S., Papioannou, E., and Perri, F. (2013a). Global banks and crisis transmission. Journal of International Economics, 89:495-510.

Kalemli-Ozcan, S., Papioannou, E., and Peydró, J. L. (2013b). Financial regulation, financial globalization and the synchronization of economic activity. Journal of Finance, 68:1179-1228.

Krugman, P. (1979). Increasing returns, monopolistic competition, and international trade. Journal of International Economics, 9:469-79. 
Kubelec, C. and Sá, F. (2010). The geographical composition of national external balance sheets: 1980-2005. Bank of England Working Paper 384.

Laeven, L. and Valencia, F. (2013). Systemic banking crises database. IMF Economic Review, $61(2): 225-270$.

Manova, K. (2008). Credit constraints, equity market liberalizations and international trade. Journal of International Economics, 76:33-47.

Manova, K. and Foley, F. (2015). International trade, multinational activity, and corporate finance. Annual Review of Economics, 7:119-146.

May, R. M. and Arinaminpathy, N. (2010). Systemic risk: the dynamics of model banking systems. Journal of the Royal Society Interface, 7:823-838.

Mian, A. (2006). Distance constraints: The limits of foreign lending in poor economies. Journal of Finance, 61:1465-1505.

Michalski, T. and Ors, E. (2012). (Inter-state) banking and (inter-state) trade: does real integration follow financial integration? Journal of Financial Economics, 104:89-117.

Miller, S. and Chew, W. (2011). A guide to the loan market. Technical Report September, Standard \& Poor's.

Minetti, R. and Zhu, S. C. (2011). Credit constraints and firm export: Microeconomic evidence from Italy. Journal of International Economics, 83(2):109-125.

Minoiu, C. and Reyes, J. A. (2013). A network analysis of global banking: 1978-2009. Journal of Financial Stability, 9:168-84.

Miura, H. (2011). Sgl stata graph library for network analysis. The Stata Journal, 12:94-129.

Niepmann, F. and Schmidt-Eisenlohr, T. (2013). Banks in international trade finance: Evidence from the U.S. FRBNY Staff Report 633.

Nier, E., Yang, J., Yorulmazer, T., and Alentorn, A. (2007). Network models and financial stability. Journal of Economic Dynamics and Control, 31(6):2033-60.

Nunn, N. (2007). Relationship-specificity, incomplete contracts and the pattern of trade. Quarterly Journal of Economics, 122(2):569-600. 
Olsen, M. (2013). How firms overcome weak intrenational contract enforcement: Repeated interaction, collective punishment and trade finance. Available at SSRN: http://ssrn.com/abstract=2219243 or http://dx.doi.org/10.2139/ssrn.2219243.

Paravisini, D., Rappoport, V., Schnabl, P., and Wolfenzon, D. (2011). Dissecting the effect of credit supply on trade: Evidence from matched credit-export data. NBER WP 16975.

Poole, J. (2012). Business travel as an input to international trade. mimeo.

Ranjan, P. and Lee, J. Y. (2007). Contract enforcement and international trade. Economics and Politics, 19(2):191-218.

Rauch, J. E. (1999). Networks versus markets in international trade. Journal of International Economics, 48:7-35.

Rauch, J. E. (2001). Business and social networks in international trade. Journal of Economic Literature, XXXIX:1177-1203.

Rauch, J. E. and Trinidade, V. (2002). Ethnic chinese networks in international trade. The Review of Economics and Statistics, 84(1):116-130.

Rodrik, D., Subramanian, A., and Trebbi, F. (2004). Institutions rule: The primacy of institutions over geography and integration in economic development. Journal of Economic Growth, 9(2):131165.

Sachs, A. (2014). Completeness, interconnectedness and distribution of interbank exposures a parameterized analysis of the stability of financial networks. Quantitative Finance, 14(9).

Santos Silva, J. and Tenreyro, S. (2006). The log of gravity. The Review of Economics and Statistics, 88:641-658.

Santos Silva, J. and Tenreyro, S. (2010). On the existence of the maximum likelihood estimates in posson regression. Economic Letters, 107:310-312.

Schmidt-Eisenlohr, T. (2013). Towards a theory of trade finance. Journal of International Economics, 91(1):96-112.

Seth, R., Nolle, D. E., and Mohanty, S. K. (1998). Do banks follow their customers abroad? Financial Markets, Insitutions $\&$ Instruments, 7(4).

von Peter, G. (2007). International banking centres: a network perspective. BIS Quarterly Review, December:33-45. 
Figure 1: Measures of Bank Linkages
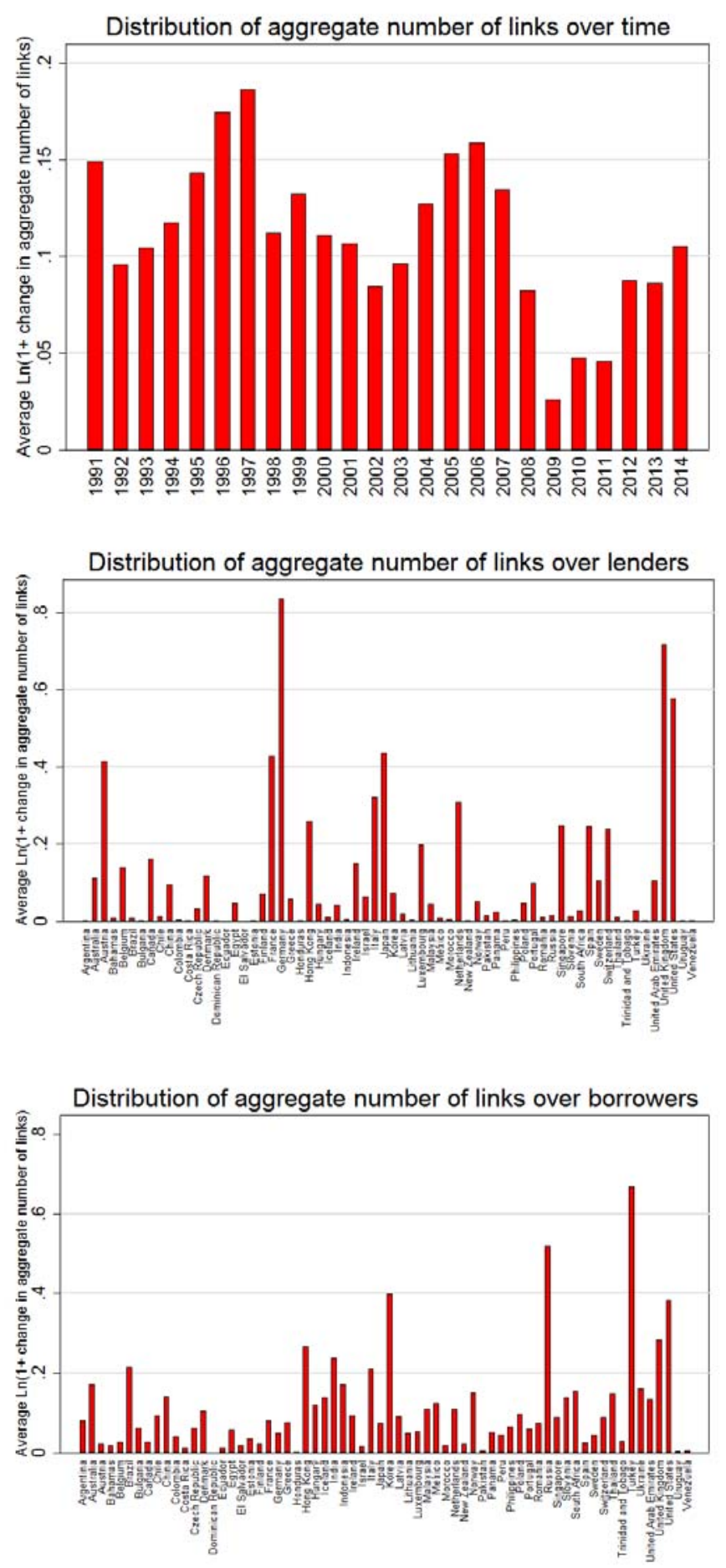


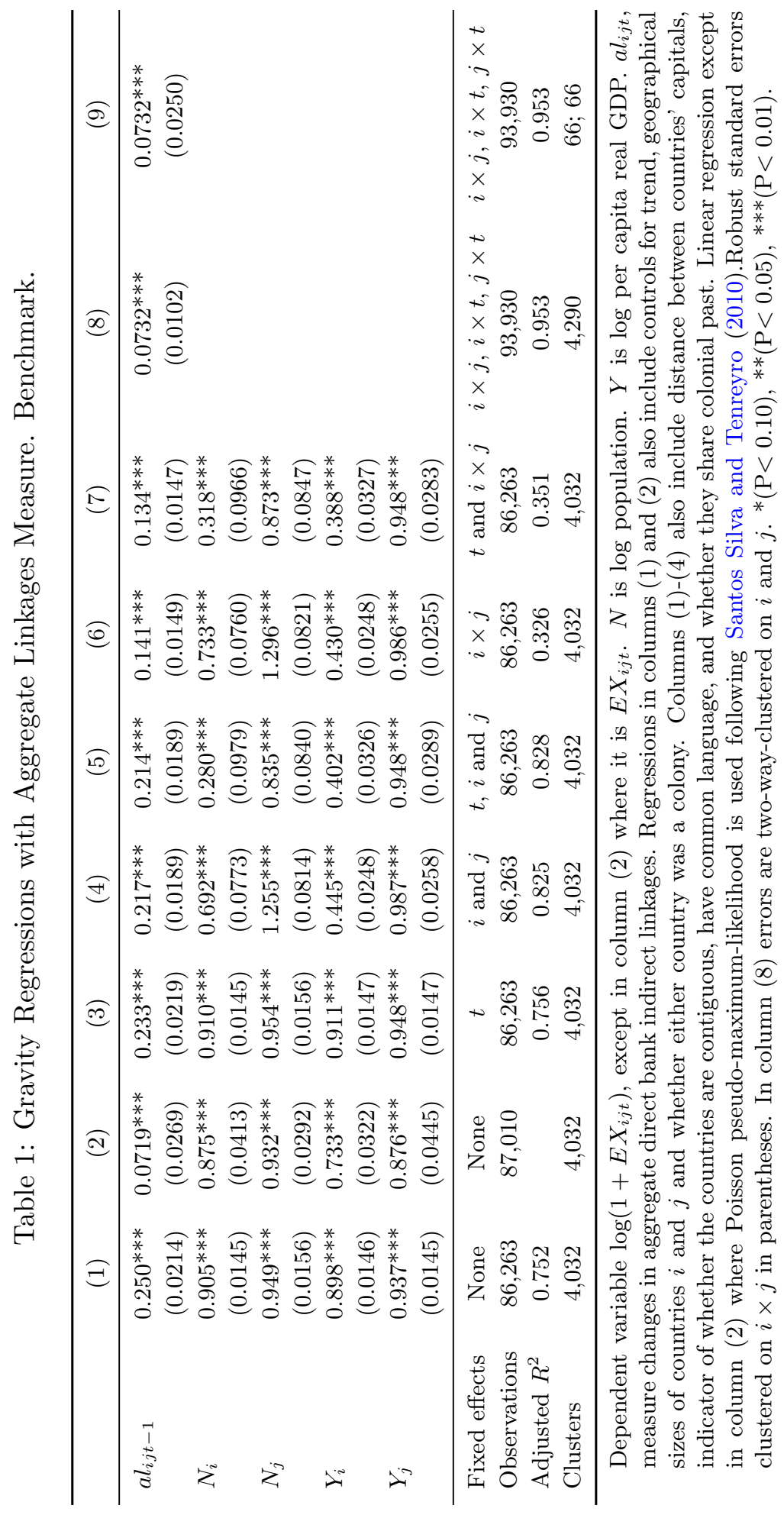


Table 2: Gravity Regressions with Aggregate Linkages and Risk Measures.

\begin{tabular}{lccc}
\hline Risk measure $(\rho)$ & $\begin{array}{c}\text { ICRG PC1 } \\
(1)\end{array}$ & $\begin{array}{c}\text { S\&P rating } \\
(2)\end{array}$ & $\begin{array}{c}\text { insurance cost } \\
(3)\end{array}$ \\
\hline$a l_{i j t-1}$ & $0.0564^{* * *}$ & 0.00567 & -0.0313 \\
& $(0.015)$ & $(0.015)$ & $(0.021)$ \\
$a l_{i j t-1} \times \rho_{i t}$ & 0.00699 & -0.00128 & \\
& $(0.0058)$ & $(0.00278)$ & \\
$a l_{i j t-1} \times \rho_{j t}$ & $-0.0238^{* * * *}$ & $0.00669^{* * *}$ & $0.0625^{* *}$ \\
& $(0.0049)$ & $(0.0015)$ & $(0.0308)$ \\
\hline Observations & 90,550 & 91,016 & 39,633 \\
Adjusted $R^{2}$ & 0.955 & 0.955 & 0.963 \\
Clusters & 4,290 & 4,160 & 1,885 \\
\hline
\end{tabular}

Dependent variable $\log \left(1+E X_{i j t}\right)$. Full set of fixed effects $(i \times j$, $i \times t, j \times t)$ included in all regressions. $a l_{i j t}$ measures changes in aggregate direct bank linkages. ICRG PC1 is the first principal component of the ICRG indexes which loads positively on all its components - see footnote 26 for details. Higher ICRG index is associated with lower risk. S\&P ratings are coded in a linear fashion with 1 corresponding to AAA,+ 2 to AAA, etc. 21 to CCC-, and 28 to SD. Robust standard errors clustered on $i \times j$ , are in parentheses. $*(\mathrm{P}<0.10),{ }^{* *}(\mathrm{P}<0.05),{ }^{* * *}(\mathrm{P}<0.01)$.

Table 3: Gravity Regressions with Aggregate Linkages by Country Group.

\begin{tabular}{lcccc}
\hline & OECD11 & OECD10 & OECD01 & OECD00 \\
& $(1)$ & $(2)$ & $(3)$ & $(4)$ \\
\hline$a l_{i j t-1}$ & -0.00404 & $0.0686^{* * *}$ & -0.00593 & $0.102^{* * *}$ \\
& $(0.00689)$ & $(0.0116)$ & $(0.0350)$ & $(0.0264)$ \\
\hline Observations & 10,864 & 21,637 & 21,469 & 39,960 \\
Adjusted $R^{2}$ & 0.988 & 0.963 & 0.965 & 0.917 \\
Clusters & 506 & 989 & 989 & 1,806 \\
\hline
\end{tabular}

Dependent variable $\log \left(1+E X_{i j t}\right)$. Full set of fixed effects $(i \times j, i \times t, j \times t)$ included in all regressions. al $l_{i j t}$ measures changes in aggregate direct bank linkages. OECDij indicates OECD membership $(0,1)$ of $i$ and $j$ countries in each pair and year. Robust standard errors clustered on $i \times j$ are in parentheses. $*(\mathrm{P}<0.10),{ }^{* *}(\mathrm{P}<0.05), * * *(\mathrm{P}<0.01)$. 
Table 4: Gravity Regressions with Aggregate Linkages Measure by Rauch (1999) (liberal) Category of Exports.

\begin{tabular}{lccc}
\hline & $\begin{array}{c}\text { Homogeneous } \\
(1)\end{array}$ & $\begin{array}{c}\text { Reference } \\
(2)\end{array}$ & $\begin{array}{c}\text { Differentiated } \\
(3)\end{array}$ \\
\hline$a l_{i j t-1}$ & $0.0115^{*}$ & $0.0233^{* * *}$ & $0.0541^{* * *}$ \\
& $(0.0062)$ & $(0.0049)$ & $(0.0065)$ \\
\hline Observations & 93,930 & 93,930 & 93,930 \\
Adjusted $R^{2}$ & 0.915 & 0.952 & 0.964 \\
Clusters & 4,290 & 4,290 & 4,290 \\
\hline
\end{tabular}

Dependent variable $\log \left(1+E X_{i j t}\right)$. Full set of fixed effects $(i \times j, i \times t, j \times t)$ included in all regressions. al $l_{i j t}$ measures changes in aggregate direct bank linkages. Robust standard errors clustered on $i \times j$ are in parentheses. $*(\mathrm{P}<0.10)$, $* *(\mathrm{P}<0.05), * * *(\mathrm{P}<0.01)$.

Table 5: Industry-level Regressions with Aggregate Linkages Measure Interacted with Rauch (1999) (liberal) Category of Exports.

\begin{tabular}{lcccc}
\hline Cluster on: & $i \times j$ & $i$ and $j$ & $i \times j$ & $i$ and $j$ \\
& $(1)$ & $(2)$ & $(3)$ & $(4)$ \\
\hline$a l_{i j t-1} \times$ Reference goods & $0.0078^{* * *}$ & $0.0078^{* * *}$ & $0.0084^{* * *}$ & $0.0084^{* * *}$ \\
& $(0.0009)$ & $(0.0021)$ & $(0.0012)$ & $(0.0025)$ \\
$a l_{i j t-1} \times$ Differentiated goods & $0.0181^{* * *}$ & $0.0181^{* * *}$ & $0.0186^{* * *}$ & $0.0186^{* * *}$ \\
& $(0.0019)$ & $(0.0049)$ & $(0.0022)$ & $(0.0047)$ \\
\hline Observations & $61,483,292$ & $61,483,292$ & $17,651,401$ & $17,651,401$ \\
Adjusted $R^{2}$ & 0.185 & 0.185 & 0.227 & 0.227 \\
Clusters & 4,290 & $66 ; 66$ & 4,278 & $66 ; 66$ \\
\hline
\end{tabular}

Dependent variable $\log \left(1+E X_{i j k t}\right) . k$ is industry. Industry (SITC4) and $i \times j \times t$ fixed effects included in all regressions. $a l_{i j t}$ measures changes in aggregate direct bank linkages. First two columns include all observations. Second two columns exclude zeros. Robust standard errors clustered as indicated are in parentheses. $*(\mathrm{P}<0.10), * *(\mathrm{P}<0.05), * * *(\mathrm{P}<0.01)$. 
Table 6: Gravity Regressions of exports to competing importers.

\begin{tabular}{lcc}
\hline Cluster on: & $i \times j$ & $i$ and $j$ \\
& $(1)$ & $(2)$ \\
\hline$a l_{i k t-1}$ & $-0.0345^{* * *}$ & $-0.0345^{* *}$ \\
& $(0.0127)$ & $(0.0152)$ \\
\hline Observations & 57,372 & 57,372 \\
Adjusted $R^{2}$ & 0.856 & 0.856 \\
Clusters & 4,133 & $66 ; 66$ \\
\hline
\end{tabular}

Dependent variable $\log \left(1+E X_{i k t}\right)$. Full set of fixed effects $(i \times j, i \times t, j \times t)$ included in all regressions. al $l_{i j t}$ measures changes in aggregate direct bank linkages. Robust standard errors clustered as indicated are in parentheses. $*(\mathrm{P}<0.10), * *(\mathrm{P}<0.05)$, $* * *(\mathrm{P}<0.01)$.

Table 7: Gravity regression with aggregate linkages and letter of credit exposures.

\begin{tabular}{|c|c|c|c|c|c|}
\hline Dependent variable & $\begin{array}{c}\log \left(1+E X_{U S j t}\right) \\
(1)\end{array}$ & $\begin{array}{c}\log \left(1+E X_{U S j t}\right) \\
(2)\end{array}$ & $\begin{array}{c}\log \left(1+L C_{U S j t}\right) \\
(3)\end{array}$ & $\begin{array}{c}\log \left(1+E X_{U S j t}\right) \\
(4)\end{array}$ & $\log \left(1+E X_{U S j t}\right)$ \\
\hline$a l_{i j t-1}$ & $\begin{array}{c}0.204^{* * *} \\
(0.063)\end{array}$ & & $\begin{array}{c}0.187^{* * *} \\
(0.042)\end{array}$ & & $\begin{array}{c}0.162^{* * *} \\
(0.0563)\end{array}$ \\
\hline $\log \left(1+L C_{U S j t}\right)$ & & $\begin{array}{c}0.277^{* * * *} \\
(0.081)\end{array}$ & & & $\begin{array}{c}0.226^{* * *} \\
(0.073)\end{array}$ \\
\hline $\begin{array}{l}\text { Predicted } \\
\qquad \log \left(1+L C_{U S j t}\right)\end{array}$ & & & & $\begin{array}{c}1.091^{* * *} \\
(0.334)\end{array}$ & \\
\hline Observations & 1,460 & 1,460 & 1,460 & 1,460 & 1,460 \\
\hline Adjusted $R^{2}$ & 0.722 & 0.723 & 0.826 & 0.722 & 0.725 \\
\hline Clusters & 65 & 65 & 65 & 65 & 65 \\
\hline
\end{tabular}

Dependent variable $\log \left(1+E X_{i j t}\right) . L C$ is Letter of Credit exposures in real U.S. dollars. $j$ and $t$ fixed effects included in all regressions. al $l_{i j t}$ measures changes in aggregate direct bank linkages. Robust standard errors clustered on $j$ are in parentheses. $*(\mathrm{P}<0.10),{ }^{* *}(\mathrm{P}<0.05),{ }^{* * *}(\mathrm{P}<0.01)$. 


\section{Appendix. Additional Charts and Tables}

Figure A.1: Distribution of Exports. UN-COMTRADE aggregate data

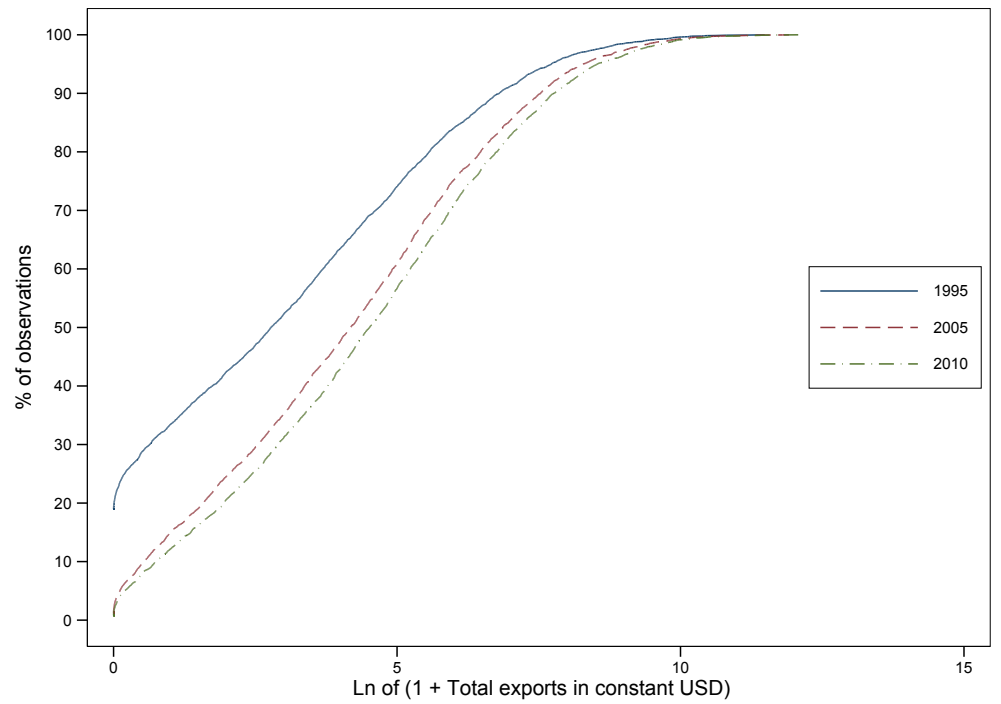

Figure A.2: Distribution of Exports. IMF DOTS data

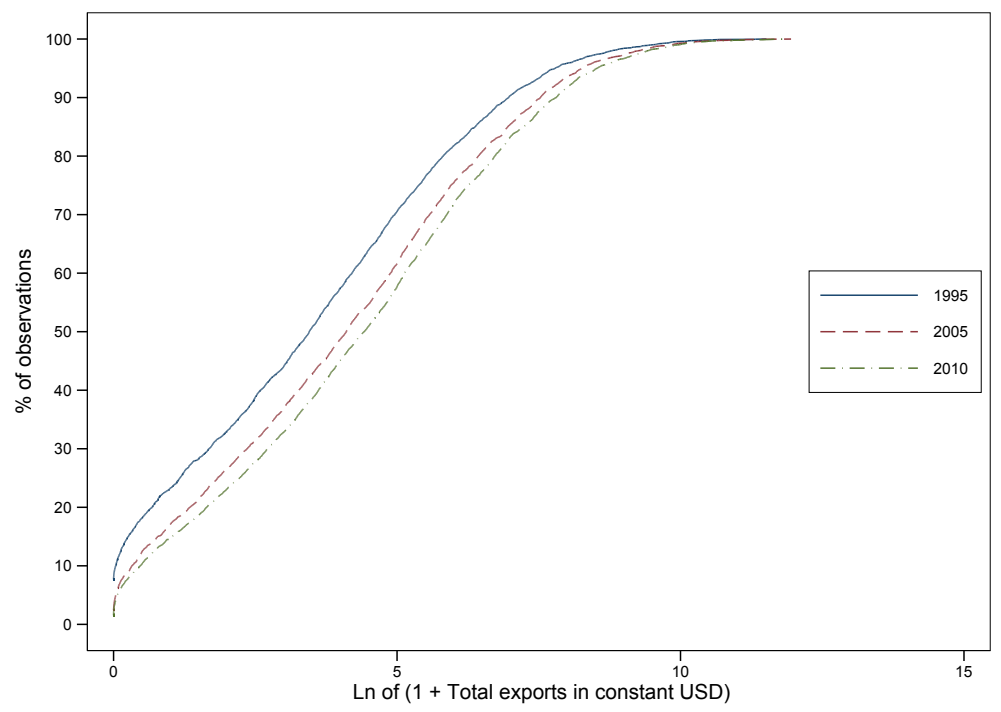


Table A.1: Robustness tests 1: sample and data source.

\begin{tabular}{|c|c|c|c|c|c|c|}
\hline & $\begin{array}{c}\text { Year }<2008 \\
(1)\end{array}$ & $\begin{array}{c}\text { Exclude China } \\
\qquad(2)\end{array}$ & $\begin{array}{l}\text { Exclude US } \\
\qquad(3)\end{array}$ & $\begin{array}{l}\text { Exclude Islands } \\
\text { (4) }\end{array}$ & $\begin{array}{l}\text { Exclude zeros } \\
\text { (5) }\end{array}$ & $\begin{array}{c}\text { IMF DOTS trade data } \\
(6)\end{array}$ \\
\hline$a l_{i j t-1}$ & $\begin{array}{c}0.0718^{* * *} \\
(0.0107)\end{array}$ & $\begin{array}{c}0.0695^{* * *} \\
(0.0102)\end{array}$ & $\begin{array}{c}0.0739 * * * \\
(0.0109)\end{array}$ & $\begin{array}{c}0.0665^{* * *} \\
(0.0100)\end{array}$ & $\begin{array}{c}0.0244^{* * *} \\
(0.00702)\end{array}$ & $\begin{array}{c}0.0247^{* * *} \\
(0.00473)\end{array}$ \\
\hline Observations & 68,190 & 91,016 & 91,016 & 88,148 & 89,122 & 93,657 \\
\hline Adjusted $R^{2}$ & 0.956 & 0.952 & 0.950 & 0.954 & 0.964 & 0.969 \\
\hline Clusters & 4,290 & 4,160 & 4,160 & 4,032 & 4,280 & 4,288 \\
\hline
\end{tabular}

Dependent variable $\log \left(1+E X_{i j t}\right)$. Full set of fixed effects $(i \times j, i \times t, j \times t)$ included in all regressions. al $l_{i j t}$ measures changes in aggregate direct bank linkages. Robust standard errors two-way clustered on $i$ and $j$ are in parentheses. $*(\mathrm{P}<0.10), * *(\mathrm{P}<0.05), * * *(\mathrm{P}<0.01)$.

Table A.2: Robustness tests 2: time-varying pair-level controls.

\begin{tabular}{|c|c|c|c|c|c|c|}
\hline & (1) & (2) & (3) & (4) & (5) & (6) \\
\hline$a l_{i j t-1}$ & $\begin{array}{c}0.0720^{* * * *} \\
(0.0101)\end{array}$ & $\begin{array}{c}0.0730^{* * * *} \\
(0.0102)\end{array}$ & $\begin{array}{c}0.0665^{* * *} \\
(0.00960)\end{array}$ & $\begin{array}{c}0.0242^{* * *} \\
(0.00476)\end{array}$ & $\begin{array}{c}0.0736^{* * *} \\
(0.0101)\end{array}$ & $\begin{array}{l}0.0570^{* * *} \\
(0.00948)\end{array}$ \\
\hline $\begin{array}{l}i \text { and } j \text { in } \\
\text { common RTA }\end{array}$ & $\begin{array}{c}0.146^{* * *} \\
(0.024)\end{array}$ & & & & & $\begin{array}{c}0.173^{* * *} \\
(0.025)\end{array}$ \\
\hline $\begin{array}{l}i \text { and } j \text { have } \\
\text { same currency }\end{array}$ & & $\begin{array}{r}-0.0548 \\
(0.036)\end{array}$ & & & & \\
\hline$\% \Delta E_{i j}$ & & & $\begin{array}{c}0.00009 \\
(0.00006)\end{array}$ & & & \\
\hline $\begin{array}{r}\text { Bank crises in } \\
\text { both } i \text { and } j\end{array}$ & & & & $\begin{array}{c}0.0271^{*} \\
(0.016)\end{array}$ & & $\begin{array}{l}0.0511^{*} \\
(0.029)\end{array}$ \\
\hline $\begin{array}{l}\text { Debt crises in } \\
\text { both } i \text { and } j\end{array}$ & & & & $\begin{array}{l}0.0501 \\
(0.078)\end{array}$ & & $\begin{array}{c}0.353 \\
(0.347)\end{array}$ \\
\hline $\begin{array}{l}\text { Currency crises } \\
\text { both } i \text { and } j\end{array}$ & & & & $\begin{array}{l}-0.117 \\
(0.074)\end{array}$ & & $\begin{array}{c}-0.256^{* * *} \\
(0.072)\end{array}$ \\
\hline$b s_{i j t}$ & & & & & $\begin{array}{c}-0.0607^{* * *} \\
(0.019)\end{array}$ & $\begin{array}{c}-0.0501^{* *} \\
(0.0197)\end{array}$ \\
\hline$b s_{j i t}$ & & & & & $\begin{array}{c}0.0631^{* * *} \\
(0.019)\end{array}$ & $\begin{array}{c}0.0763^{* * *} \\
(0.020)\end{array}$ \\
\hline$b f_{i j t}$ & & & & & $\begin{array}{l}0.0009 \\
(0.036)\end{array}$ & $\begin{array}{l}-0.0005 \\
(0.0034)\end{array}$ \\
\hline$b f_{j i t}$ & & & & & $\begin{array}{c}-0.008^{* *} \\
(0.0035)\end{array}$ & $\begin{array}{c}-0.010^{* * *} \\
(0.0035)\end{array}$ \\
\hline Observations & 93,930 & 93,930 & 93,573 & 83,867 & 93,930 & 84,052 \\
\hline Adjusted $R^{2}$ & 0.953 & 0.953 & 0.953 & 0.971 & 0.953 & 0.956 \\
\hline Clusters & 4,290 & 4,290 & 4,290 & 4,029 & 4,290 & 4,029 \\
\hline
\end{tabular}

Dependent variable $\log \left(1+E X_{i j t}\right)$. Full set of fixed effects $(i \times j, i \times t, j \times t)$ included in all regressions. $a l_{i j t}$ measures changes in aggregate direct bank linkages. RTA is regional trade agreement. $E_{i j}$ is the $i j$ exchange rate, year average. $b s_{i j t}, b s_{j i t}, b f_{i j t}, b f_{j i t}$ are measures of stocks and flows of bank claims from BIS. Robust standard errors two-way clustered on $i$ and $j$ are in parentheses. $*(\mathrm{P}<0.10),{ }^{* *}(\mathrm{P}<0.05),{ }^{* * *}(\mathrm{P}<0.01)$. 
Table A.3: Summary Statistics

\begin{tabular}{|c|c|c|c|c|c|}
\hline Variable & Obs & Mean & Std. Dev. & Min & $\operatorname{Max}$ \\
\hline \multicolumn{6}{|l|}{ Country-pair-year level } \\
\hline Log real exports & 98220 & 3.83 & 2.62 & 0 & 12.19 \\
\hline \multicolumn{6}{|l|}{ Bank linkages } \\
\hline Share of directly linked bank pairs & 98220 & 0.22 & 0.40 & 0 & 1 \\
\hline Number of bank pairs & 98220 & 6.09 & 33.3 & 0 & 1037 \\
\hline Number of banks directly linked $A L$ & 98220 & 5.45 & 31.2 & 0 & 1037 \\
\hline Log change in number of direct links al & 98220 & 0.10 & 0.41 & 0 & 5.31 \\
\hline - in regression sample & 93930 & 0.11 & 0.42 & 0 & 5.31 \\
\hline \multicolumn{6}{|l|}{ Control variables (in regression sample) } \\
\hline Regional trade agreement & 93930 & 0.23 & 0.42 & 0 & 1 \\
\hline Common currency & 93930 & 0.025 & 0.16 & 0 & 1 \\
\hline Percentage change in exchange rate & 93573 & 8.39 & 3197 & -0.999 & 16312 \\
\hline Country-pair bank crisis & 84052 & 0.0055 & 0.074 & 0 & 1 \\
\hline Country-pair debt crisis & 84052 & .00005 & 0.007 & 0 & 1 \\
\hline Country-pair currency crisis & 84052 & .00015 & 0.012 & 0 & 1 \\
\hline$b s_{i j t}$ & 93930 & 0.19 & 0.63 & 0 & 6.57 \\
\hline$b f_{i j t}$ & 93930 & 0.024 & 0.33 & -4.96 & 4.86 \\
\hline \multicolumn{6}{|l|}{ Country-year level } \\
\hline$N_{i}$ & 92412 & 2.85 & 1.69 & -1.36 & 7.22 \\
\hline$Y_{i}$ & 92412 & 8.51 & 1.26 & 5.17 & 10.9 \\
\hline ICRG PC1 & 92174 & 0.06 & 2.21 & -7.30 & 4.03 \\
\hline $\mathrm{S} \& \mathrm{P}$ credit rating & 92469 & 9.37 & 5.38 & 2 & 28 \\
\hline Export insurance premium & 39860 & 0.58 & 0.20 & 0 & 1.79 \\
\hline
\end{tabular}


Table A.4: Components of ICRG Ppolitical Risk Index

\begin{tabular}{|c|c|}
\hline Component & Description \\
\hline $\begin{array}{l}\text { Government } \\
\text { Stability }\end{array}$ & $\begin{array}{l}\text { This is an assessment both of the government's ability to carry out its declared program(s), } \\
\text { and its ability to stay in office. The risk rating assigned is the sum of three subcomponents } \\
\text { (Government Unity, Legislative Strength and Popular Support). }\end{array}$ \\
\hline $\begin{array}{l}\text { Socioeconomic } \\
\text { Conditions }\end{array}$ & $\begin{array}{l}\text { This is an assessment of the socioeconomic pressures at work in society that could constrain } \\
\text { government action or fuel social dissatisfaction. The risk rating assigned is the sum of three } \\
\text { subcomponents Unemployment, Consumer Confidence and Poverty. }\end{array}$ \\
\hline $\begin{array}{l}\text { Investment } \\
\text { Profile }\end{array}$ & $\begin{array}{l}\text { This is an assessment of factors affecting the risk to investment that are not covered by other } \\
\text { political, economic and financial risk components. The risk rating assigned is the sum of three } \\
\text { subcomponents Contract Viability/Expropiation, Profits Repatriation and Payment Delays. }\end{array}$ \\
\hline $\begin{array}{l}\text { Internal Con- } \\
\text { flict }\end{array}$ & $\begin{array}{l}\text { This is an assessment of political violence in the country and its actual or potential impact } \\
\text { on governance. The highest rating is given to those countries where there is no armed or civil } \\
\text { opposition to the government and the government does not indulge in arbitrary violence, direct } \\
\text { or indirect, against its own people. The lowest rating is given to a country embroiled in an } \\
\text { on-going civil war. The risk rating assigned is the sum of three subcomponents Civil War/Coup } \\
\text { Threat, Terrorism/Political Violence and Civil Disorder. }\end{array}$ \\
\hline $\begin{array}{l}\text { External } \\
\text { Conflict }\end{array}$ & $\begin{array}{l}\text { The external conflict measure is an assessment both of the risk to the incumbent government } \\
\text { from foreign action, ranging from non-violent external pressure (diplomatic pressures, withhold- } \\
\text { ing of aid, trade restrictions, territorial disputes, sanctions, etc) to violent external pressure } \\
\text { (cross-border conflicts to all-out war). External conflicts can adversely affect foreign business } \\
\text { in many ways, ranging from restrictions on operations to trade and investment sanctions, to } \\
\text { distortions in the allocation of economic resources, to violent change in the structure of society. } \\
\text { The risk rating assigned is the sum of three subcomponents War, Cross-Border Conflict and } \\
\text { Foreign Pressures. }\end{array}$ \\
\hline Corruption & $\begin{array}{l}\text { This is an assessment of corruption within the political system. Such corruption is a threat } \\
\text { to foreign investment for several reasons: it distorts the economic and financial environment; } \\
\text { it reduces the efficiency of government and business by enabling people to assume positions of } \\
\text { power through patronage rather than ability; and, last but not least, introduces an inherent } \\
\text { instability into the political process. The most common form of corruption met directly by } \\
\text { business is financial corruption in the form of demands for special payments and bribes con- } \\
\text { nected with import and export licenses, exchange controls, tax assessments, police protection, } \\
\text { or loans. Such corruption can make it difficult to conduct business effectively, and in some } \\
\text { cases may force the withdrawal or withholding of an investment. }\end{array}$ \\
\hline
\end{tabular}


Table A.4: Components of ICRG Ppolitical Risk Index (continuation)

\begin{tabular}{|c|c|}
\hline Component & Description \\
\hline $\begin{array}{l}\text { Military in } \\
\text { Politics }\end{array}$ & $\begin{array}{l}\text { The military is not elected by anyone. Therefore, its involvement in politics, even at a peripheral } \\
\text { level, is a diminution of democratic accountability. However, it also has other significant } \\
\text { implications. The military might, for example, become involved in government because of an } \\
\text { actual or created internal or external threat. Such a situation would imply the distortion of } \\
\text { government policy in order to meet this threat, for example by increasing the defense budget at } \\
\text { the expense of other budget allocations. In some countries, the threat of military take-over can } \\
\text { force an elected government to change policy or cause its replacement by another government } \\
\text { more amenable to the militarys wishes. A military takeover or threat of a takeover may also } \\
\text { represent a high risk if it is an indication that the government is unable to function effectively } \\
\text { and that the country therefore has an uneasy environment for foreign businesses. A full-scale } \\
\text { military regime poses the greatest risk. Overall, lower risk ratings indicate a greater degree of } \\
\text { military participation in politics and a higher level of political risk. }\end{array}$ \\
\hline $\begin{array}{l}\text { Religion in } \\
\text { Politics }\end{array}$ & $\begin{array}{l}\text { Religious tensions may stem from the domination of society and/or governance by a single } \\
\text { religious group that seeks to replace civil law by religious law and to exclude other religions } \\
\text { from the political and/or social process; the desire of a single religious group to dominate } \\
\text { governance; the suppression of religious freedom; the desire of a religious group to express its } \\
\text { own identity, separate from the country as a whole. The risk involved in these situations range } \\
\text { from inexperienced people imposing inappropriate policies through civil dissent to civil war. }\end{array}$ \\
\hline $\begin{array}{l}\text { Law and Or- } \\
\text { der }\end{array}$ & $\begin{array}{l}\text { Law and Order are assessed separately, with each sub-component comprising zero to three } \\
\text { points. The Law sub-component is an assessment of the strength and impartiality of the legal } \\
\text { system, while the Order sub-component is an assessment of popular observance of the law. }\end{array}$ \\
\hline $\begin{array}{l}\text { Ethnic Ten- } \\
\text { sions }\end{array}$ & $\begin{array}{l}\text { This component is an assessment of the degree of tension within a country attributable to } \\
\text { racial, nationality, or language divisions. Lower ratings are given to countries where racial } \\
\text { and nationality tensions are high because opposing groups are intolerant and unwilling to } \\
\text { compromise. Higher ratings are given to countries where tensions are minimal, even though } \\
\text { such differences may still exist. }\end{array}$ \\
\hline $\begin{array}{l}\text { Democratic } \\
\text { Accountabil- } \\
\text { ity }\end{array}$ & $\begin{array}{l}\text { This is a measure of how responsive government is to its people, on the basis that the less } \\
\text { responsive it is, the more likely it is that the government will fall, peacefully in a democratic } \\
\text { society, but possibly violently in a non-democratic one. The points in this component are } \\
\text { awarded on the basis of the type of governance enjoyed by the country in question. }\end{array}$ \\
\hline $\begin{array}{l}\text { Bureaucracy } \\
\text { Quality }\end{array}$ & $\begin{array}{l}\text { The institutional strength and quality of the bureaucracy is another shock absorber that tends } \\
\text { to minimize revisions of policy when governments change. Therefore, high points are given } \\
\text { to countries where the bureaucracy has the strength and expertise to govern without drastic } \\
\text { changes in policy or interruptions in government services. }\end{array}$ \\
\hline
\end{tabular}

